\title{
Intramolecular Conversions of (Aminoferrocenylpenta-1,4- dienyl)-ferrocenylcarbenes: Synthesis of Diferrocenylmono-, bi-, tricycles and Amino(diferrocenyl)hexa-1,3,5-trienes
}

\author{
Elena I. Klimova ${ }^{1{ }^{1},}$, Luis A. Ortiz-Frade ${ }^{2}$, Miguel A. González-Fuentes ${ }^{2}$, Marcos Flores-Alamo ${ }^{1}$,
} Leon V. Backinowsky ${ }^{3}$ and Marcos Martínez García ${ }^{4}$

1 Facultad de Química, Universidad Nacional Autónoma de México, Cd. Universitaria, Coyoacán, México D.F. 04510, Mexico; E-Mail: mfa24s99@gmail.com (M.F.-A.)

2 Centro de Investigación y Desarrollo Tecnológico en Electroquímica S.C. Parque Tecnológico Querétaro, Pedro de Escobedo, Querétaro 76703, Mexico; E-Mail: laofrade@gmail.com (L.A.O.-F.)

3 N. D. Zelinsky Institute of Organic Chemistry, Russian Academy of Sciences, 47 Leninsky prosp., Moscow 119991, Russia; E-Mail: leon_bakinowsky@mail.ru (L.V.B)

4 Instituto de Química, Universidad Nacional Autónoma de México, Cd. Universitaria, Coyoacán, México D.F. 04510, Mexico; E-Mail: margar@unam.mx (M.M.G.)

* Author to whom correspondence should be addressed; E-Mail: eiklimova@yahoo.com.mx; Tel. / Fax: +52-55-56225371.

Received: 23 May 2011; in revised form: 18 June 2011 / Accepted: 28 June 2011 / Published: 30 June 2011

\begin{abstract}
Synthesis of 3,4-diferrocenyltoluene (7), 1-morpholino- and 1-piperidino-2,3diferrocenylbicyclo[3.1.0]hex-2-enes 8a, 8b, 1-morpholino- and 1-piperidino-7-ferrocenyl3,4-ferrocenobicyclo[3.2.1] oct-6-enes 9a, 9b, 2- and 3-amino(diferrocenyl)-hexa-1,3,5trienes 10a,b, 11a,b by reactions of amino(diferrocenyl)cyclopropenylium tetrafluoroborates with 1-methylprop-2-enylmagnesium chloride at $80^{\circ} \mathrm{C}$ is described. The structures of the compounds obtained were determined by IR, ${ }^{1} \mathrm{H}$ - and ${ }^{13} \mathrm{C}$-NMR spectroscopy and mass spectrometry. X-ray diffraction data for 1-piperidino-7-ferrocenyl-3,4-ferrocenobicyclo[3.2.1] oct-6-ene (9b), 2-morpholino- and 2-piperidino-1,3-diferrocenyl-4-methylhexa-1,3,5-trienes 10a and 10b is presented. The electrochemical behaviour of compounds 7, 8a, 10a and 10b was investigated by means of cyclic voltammetry and square wave voltammetry. For $\mathbf{7}$ and $\mathbf{8 a}$ two electrochemical processes (I-II), attributed to the oxidation of the ferrocene moieties were found. On the other hand for compounds 10a and 10b a
\end{abstract}


single electron transfer for both ferrocene groups and the electrochemical generation of the monocation and dication species were detected.

Keywords: amino(diferrocenyl)cyclopropenylium; cyclopropene ring opening; intramolecular conversion of aminoferrocenylpenta-1,4-dienyl(ferrocenyl)carbenes; 3,4-diferrocenyltoluene; amino(diferrocenyl)bicyclo-[3.1.0]hexanes; amino(ferrocenyl)ferrocenobicyclo[3.2.1] Joctenes; amino(diferrocenyl)hexa-1,3,5-trienes; electrochemistry

\section{Introduction}

Diferrocenylcyclopropenylium cations with heterosubstituents in the small ring have recently been described [1-6]. These include 1-ethoxy-, 1-diethylamino-, 1-morpholino-, 1-piperidino-2,3diferrocenylcyclopropenylium tetrafluoroborates and 2,3-diferrocenyl-1-methylsulfanylcyclopropenylium iodide. Thus, it was established that the reactions of 1-ethoxy-2,3-diferrocenylcyclopropenylium tetrafluoroborate with orghanolithium compounds are regioselective (the nucleophilic attacks of the anionic reagents on cyclopropenylium cation are directed at both C-1 centers of the three-carbon ring) to yield 3,3-dialkyl-1,2-diferrocenylcyclopropenes [1]. We have shown that the reactions of the 2,3-diferrocenyl-1-methylsulfanylcyclopropenylium iodide with RLi and $\mathrm{RMgX}$ are nonregioselective to yield diferrocenylcycloropenes in low yields $(\sim 10 \%-20 \%)$, the major products being 2,3 diferrocenyl-1-methylsulfanyl-1,3-dienes and -1,3,5-trienes ( $60 \%-70 \%)$ [4].

On the whole, salts of the 1-morpholino- or 1-piperidino-2,3-diferrocenylcyclopropenylium series are little studied in both the synthetic and practical aspects. Previously it has been shown that 2,3-diferrocenyl-1-morpholinocyclopropenylium tetrafluoroborate (1a) reacted with $\beta$-dicarbonyl compounds and sodium cyanamide to afford initially the adducts of the nucleophiles at the small ring, i.e., tetrasubstituted diferrocenylcyclopropenes 2a-d [5-7] (Scheme 1).

Scheme 1. Reaction of 2,3-diferrocenyl-1-morpholinocyclopropenylium tetrafluoroborate 1a with $\beta$-dicarbonyl compounds.
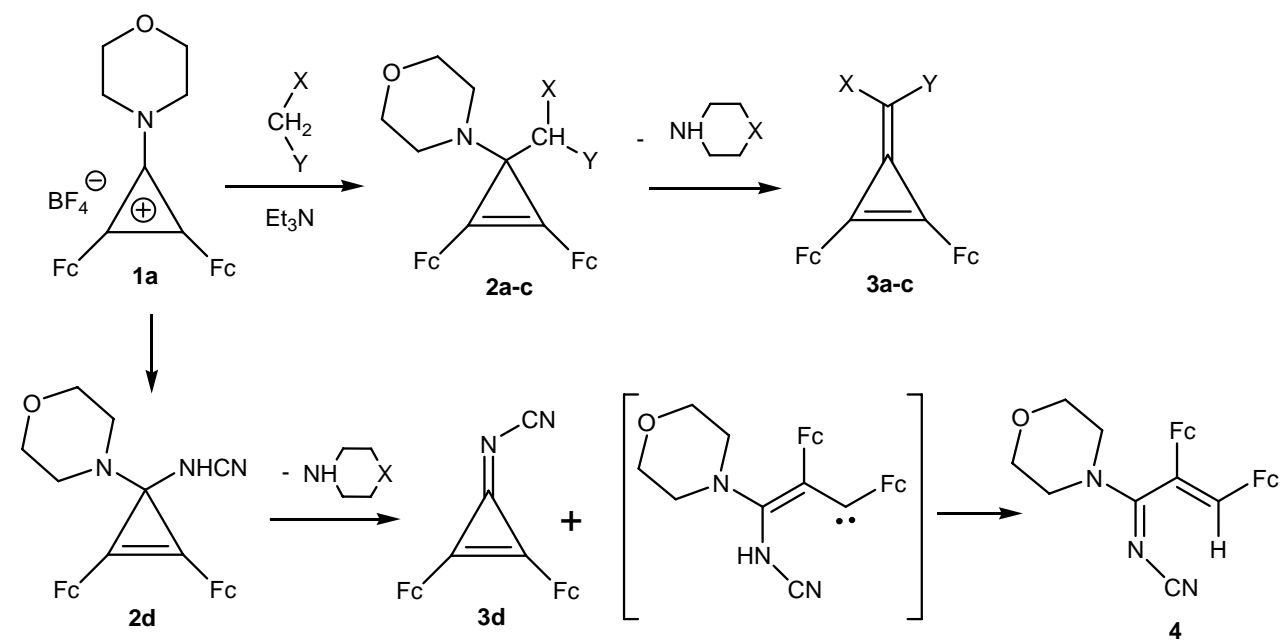
Elimination of morpholine from cyclopropenes 2a-c then resulted in 1,2-diferrocenyl-3(disubstituted)methylidenecyclopropenes 3a-c. Under the reaction conditions, 3-cyanimino-1,2diferrocenylcyclopropene (3d) and a linear conjugated product $\mathbf{4}$ formed from compound $\mathbf{2 d}$. In these reactions, the final products result from the regioselective attack of the nucleophiles on the $\mathrm{C}(1)$ atom of the three-membered ring of the cation $1 \mathbf{a}$.

The interest in these compounds, especially with heteroaryl substituents in their molecules, may stem from the peculiarities of their chemical behavior due to the mutual effects of the ferrocene system and the heterocyclic fragment [8]. These effects may result in the emergence of diverse valuable properties, such as biological activity, dyeing ability, possible use as propellant additives or light-sensitive materials, redox switching receptors in supramolecular chemistry, etc., which have previously been observed for a number of heteroarylferrocenes [8].

\section{Results and Discussion}

\subsection{Synthesis of Diferrocenylmono-, bi-, tricycles and Amino(diferrocenyl)hexa-1,3,5-trienes}

Here we report investigations into the reactions of 2,3-diferrocenyl-1-morpholino(pipe-ridino) cyclopropenylium tetrafluoroborates 1a, b with 1-methylprop-2-enylmagnesium chloride 5 (Scheme 2).

Scheme 2. Reaction of 2,3-diferrocenyl-1-morpholino(piperidino)cyclopropenylium tetrafluoroborates 1a,b with 1-methylprop-2-enylmagnesium chloride 5.
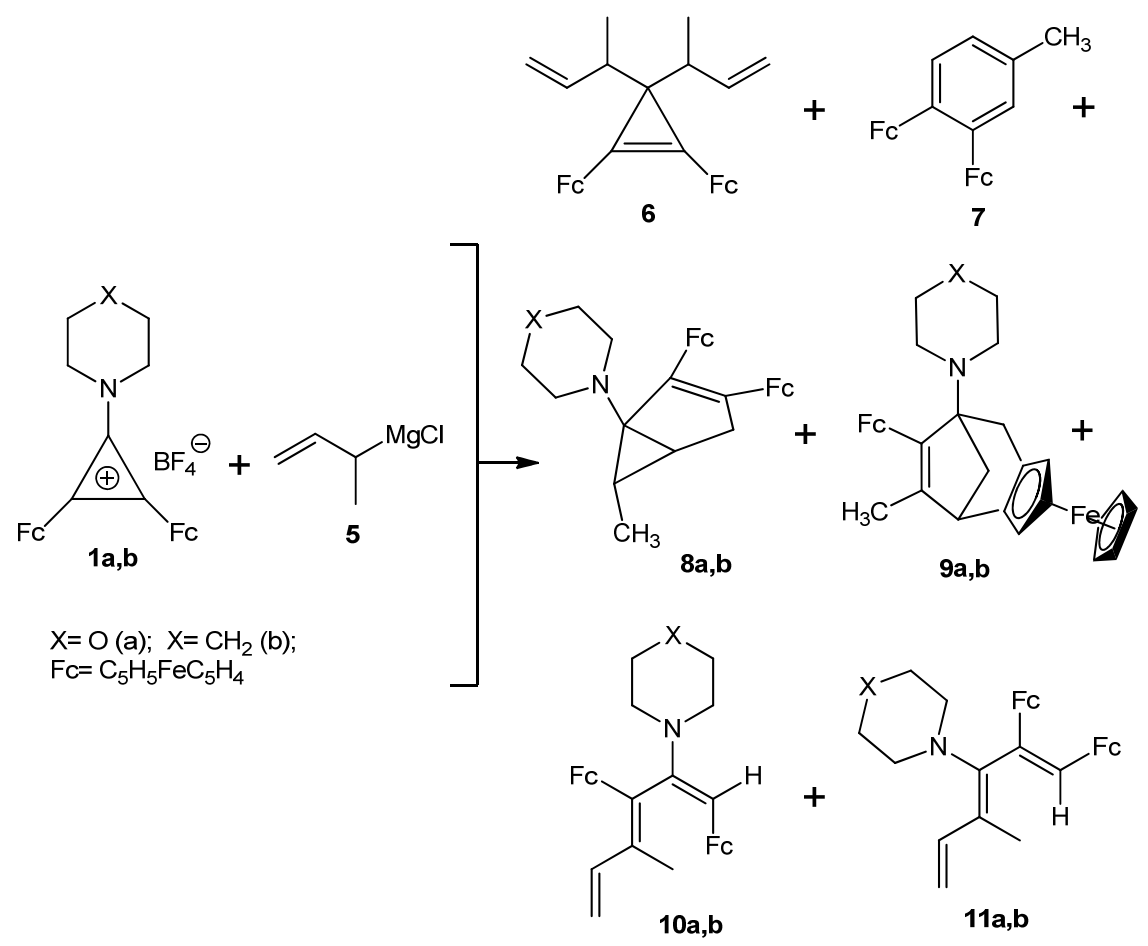

According to a standard procedure [5-7], 2,3-diferrocenylcyclopropenone [9] was first converted into 1-ethoxy-2,3-diferrocenylcyclopropenylium tetrafluoroborate and then to tetrafluoroborates $\mathbf{1 a , b}[1,2]$, which served as the starting materials in the present study.

We found that tetrafluoroborate 1a reacted with an excess of 1-methylprop-2-enylmagnesium chloride 5 to afford a complex mixture of reaction products, the main ones being 3,3-bis(1- 
methylprop-2-enyl)-1,2-diferrocenylcyclopropene (6), 3,4-diferrocenyltoluene (7), 2,3-diferrocenyl-6methyl-1-morpholinobicyclo[3.1.0]hex-2-ene (8a), 7-ferrocenyl-6-methyl-1-morpholino-3,4ferrocenobicyclo-[3.2.1] oct-6-ene $\quad(9 a), \quad(E, E)$-1,3-diferrocenyl-4-methyl-2-morpholinohexa-1,3,5triene (10a), and (Z,E)-1,2-diferrocenyl-4-methyl-3-morpholinohexa-1,3,5-triene (11a) (Scheme 2). Analogously tetrafluoroborate $\mathbf{1 b}$ reacted with the Grignard reagent 5 to give compounds $\mathbf{6 ,} \mathbf{7}, \mathbf{8 b}, \mathbf{9 b}$, 10b, and 11b (Scheme 2).

Both reaction mixtures were separated by column chromatography on alumina, and the structures of the isolated products were established based on the data from UV, IR, and ${ }^{1} \mathrm{H}-$ and ${ }^{13} \mathrm{C}-\mathrm{NMR}$ spectroscopy, mass spectrometry, and elemental analysis. The physicochemical characteristics of compounds 6 and 7 corroborate completely their structures.

We attempted to assign endo forms of compounds $\mathbf{8 a}$ and $\mathbf{8 b}$ based on previously reported criteria [10-12]. Thus, compounds $\mathbf{8 a}$ and $\mathbf{8 b}$ were characterized as endo isomers based on the fact that the signals from three of the protons of the $\mathrm{C}_{5} \mathrm{H}_{4}$ groups are observed at higher field than the singlets from the protons of the $\mathrm{C}_{5} \mathrm{H}_{5}$ groups [10]; the ${ }^{1} \mathrm{H}-\mathrm{NMR}$ spectra of compounds 8a and $\mathbf{8 b}$ each contain characteristic doublets for the protons of the methyl group ( $\delta 1.04$ and $0.97 \mathrm{ppm}$ ), two doublets of doublets for the methylene fragment, two multiplets for the methine fragments $(\delta 0.94$ and 1.77; 0.89 and $1.76 \mathrm{ppm}$ ) [11], signals for the protons of the morpholine or piperidine substituents, two singlets for unsubstituted cyclopentadienyl rings and the appropriate number of multiplet signals for two substituted $\mathrm{C}_{5} \mathrm{H}_{4}$ moieties of the ferrocenyl substituents. The ${ }^{13} \mathrm{C}$-NMR spectra of compounds 8a and $\mathbf{8 b}$ each contained two signals for $\mathrm{C}_{\mathrm{ipso}} \mathrm{Fc}$ belonging to two ferrocene fragments, as well as the necessary number of signals for cyclopropyl-fragments $\delta 13.12,20.54 \mathrm{ppm}(2 \mathrm{CH}), 20.63\left(\mathrm{CH}_{3}\right)$ from 8a, and $\delta 12.92,20.26(2 \mathrm{CH}), 21.34 \mathrm{ppm}\left(\mathrm{CH}_{3}\right)$ from $\mathbf{8 b}$ [12]. The position of the heterocyclic substituents at the $\mathrm{C}(1)$ carbon atom of the bicycles 8a,b was established based on the data from ${ }^{1} \mathrm{H}-\mathrm{NMR}$ spectra with a one-dimensional NOE experiment, which showed the interaction of the protons of the two $\mathrm{CH}$ groups with the 2- $\mathrm{CH}_{2}$-protons of the heterocycles, that completely corroborated their structures. Additional proof of the structures of compounds 9a and $\mathbf{9 b}$ was obtained from X-ray diffraction analysis of a single crystal of compound $\mathbf{9 b}$, which was grown by crystallization from $\mathrm{CH}_{2} \mathrm{Cl}_{2}$. A general view of $\mathbf{9 b}$ is shown in Figure 1a, the character of packing of molecules in a crystal is shown in Figure 1b, and the main geometrical parameters are given in Table 1. Data from the X-ray analysis proved the structure of $\mathbf{9 b}$ as 7-ferrocenyl-3,4-ferroceno-6-methyl-1-piperidinobicyclo-[3.2.1] oct-6-ene.

As inferred from the ${ }^{1} \mathrm{H}-\mathrm{NMR}$ spectra of trienes 10a and 10b, they are formed as single isomers. The spectra contained each signals for the olefinic protons of the $-\mathrm{CH}=$ fragments and the protons of the terminal $=\mathrm{CH}_{2}$ group, singlets for the $\mathrm{CH}_{3}-$ group and two $\mathrm{C}_{5} \mathrm{H}_{5}$ fragments, as well as multiplets for the protons of the heterocyclic substituents. The data from ${ }^{13} \mathrm{C}-\mathrm{NMR}$ spectroscopy of these compounds are in full accord with the proposed structures; however, the positions of the ferrocenyl and heterocyclic substituents remained uncertain. 
Figure 1. (a) X-ray crystal structure of 9b; (b) Crystal packing of 9b.

(a)

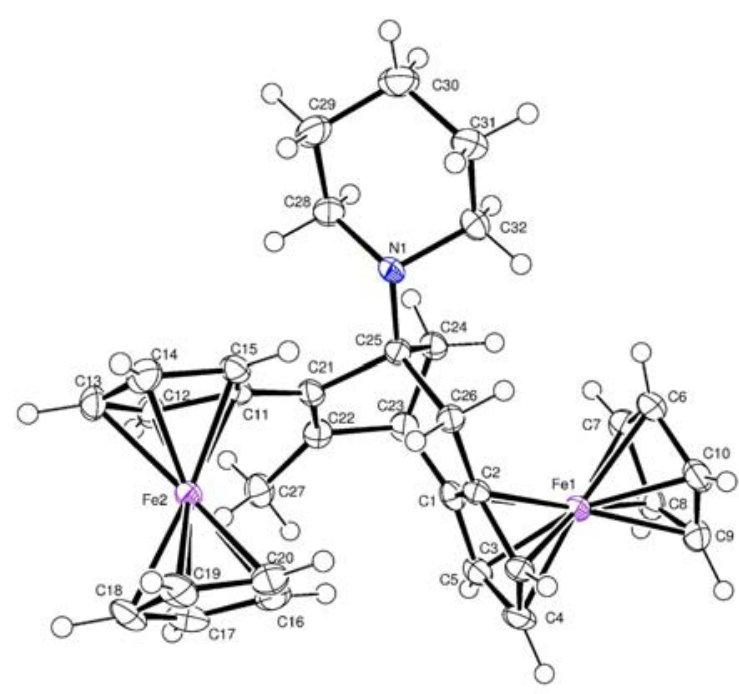

(b)

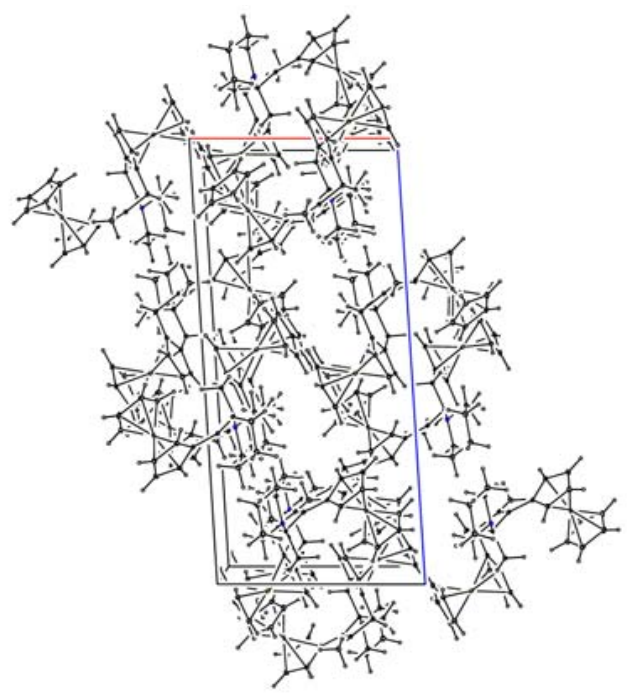

Table 1. Selected bond lengths and bond angles for $9 \mathbf{b}, \mathbf{1 0 a}$ and $\mathbf{1 0 b}$.

\begin{tabular}{|c|c|c|c|}
\hline \multicolumn{2}{|c|}{ Selected bond lengths $(\AA)$} & \multicolumn{2}{|c|}{ Selected bond angles $\left({ }^{\circ}\right)$} \\
\hline \multicolumn{2}{|c|}{$9 b$} & & \\
\hline $\mathrm{C}(21)-\mathrm{C}(22)$ & $1.346(4)$ & $\mathrm{C}(2)-\mathrm{C}(1)-\mathrm{C}(23)$ & $117.9(3)$ \\
\hline$C(22)-C(23)$ & $1.526(4)$ & $C(1)-C(2)-C(26)$ & $122.9(3)$ \\
\hline$C(23)-C(24)$ & $1.530(4)$ & $\mathrm{C}(1)-\mathrm{C}(23)-\mathrm{C}(22)$ & $105.8(2)$ \\
\hline$C(24)-C(25)$ & $1.541(4)$ & $C(23)-C(22)-C(21)$ & $109.9(3)$ \\
\hline$C(25)-C(26)$ & $1.561(4)$ & $C(22)-C(21)-C(25)$ & $109.4(3)$ \\
\hline $\mathrm{C}(25)-\mathrm{N}(1)$ & $1.473(4)$ & $C(21)-C(25)-C(26)$ & $106.7(2)$ \\
\hline$C(26)-C(2)$ & $1.514(4)$ & $\mathrm{C}(21)-\mathrm{C}(22)-\mathrm{C}(27)$ & $130.0(3)$ \\
\hline $\mathrm{C}(1)-\mathrm{C}(2)$ & $1.430(4)$ & $C(27)-C(22)-C(23)$ & $119.2(3)$ \\
\hline$C(22)-C(27)$ & $1.506(4)$ & $C(22)-C(23)-C(24)$ & $101.1(2)$ \\
\hline \multicolumn{4}{|c|}{ 10a } \\
\hline$C(21)-C(22)$ & $1.317(6)$ & $C(21)-C(22)-C(23)$ & $122.8(4)$ \\
\hline$C(22)-C(23)$ & $1.469(5)$ & $C(22)-C(23)-C(24)$ & $121.8(3)$ \\
\hline$C(23)-C(24)$ & $1.353(5)$ & $\mathrm{C}(23)-\mathrm{C}(24)-\mathrm{C}(25)$ & 121.3(3) \\
\hline$C(24)-C(25)$ & $1.518(4)$ & $C(24)-C(25)-C(26)$ & $123.2(3)$ \\
\hline$C(25)-C(26)$ & $1.336(5)$ & $C(22)-C(23)-C(27)$ & $115.8(3)$ \\
\hline$C(23)-C(27)$ & $1.495(5)$ & $C(24)-C(23)-C(27)$ & $122.4(3)$ \\
\hline $\mathrm{C}(25)-\mathrm{N}(1)$ & $1.423(4)$ & $\mathrm{C}(24)-\mathrm{C}(25)-\mathrm{N}(1)$ & $113.6(3)$ \\
\hline$C(26)-C(1)$ & $1.475(5)$ & $\mathrm{N}(1)-\mathrm{C}(25)-\mathrm{C}(26)$ & $122.7(3)$ \\
\hline$C(24)-C(11)$ & $1.489(4)$ & $C(25)-C(26)-C(1)$ & $128.7(3)$ \\
\hline \multicolumn{4}{|c|}{ 10b } \\
\hline $\mathrm{C}(22)-\mathrm{N}(1)$ & $1.414(3)$ & $C(26)-C(25)-C(24)$ & $125.9(2)$ \\
\hline$C(22)-C(23)$ & $1.501(3)$ & $C(25)-C(24)-C(23)$ & $122.1(2)$ \\
\hline$C(23)-C(24)$ & $1.343(3)$ & $C(25)-C(24)-C(27)$ & $115.8(2)$ \\
\hline$C(24)-C(25)$ & $1.468(3)$ & $C(27)-C(24)-C(23)$ & $122.1(2)$ \\
\hline$C(21)-C(22)$ & $1.343(3)$ & $C(24)-C(23)-C(22)$ & $121.3(2)$ \\
\hline$C(25)-C(26)$ & $1.326(3)$ & $C(23)-C(22)-C(21)$ & $122.7(2)$ \\
\hline$C(24)-C(27)$ & $1.510(3)$ & $\mathrm{C}(21)-\mathrm{C}(22)-\mathrm{N}(1)$ & $123.1(2)$ \\
\hline $\mathrm{C}(23)-\mathrm{C}(1)$ & $1.480(3)$ & $\mathrm{N}(1)-\mathrm{C}(22)-\mathrm{C}(23)$ & $113.90(19)$ \\
\hline $\mathrm{C}(21)-\mathrm{C}(11)$ & $1.462(3)$ & $\mathrm{C}(24)-\mathrm{C}(23)-\mathrm{C}(1)$ & $125.7(2)$ \\
\hline
\end{tabular}


To address this issue, we performed X-ray diffraction analysis of their single crystals grown by crystallization from dichloromethane. The general views of the molecules 10a and 10b are shown in Figures 2a,b and Figures 3a,b, respectively, and the main geometrical parameters are given in Table 1. Data from the X-ray analysis demonstrated that 10a is $(E, E)-1,3$-diferrocenyl-4-methyl-2-morpholinohexa-1,3,5-triene, and $\mathbf{1 0 b}$ is (E,E)-1,3-diferrocenyl-4-methyl-2-piperidinohexa-1,3,5-triene.

Figure 2. (a) X-ray crystal structure of 10a; (b) Crystal packing of 10a.

(a)

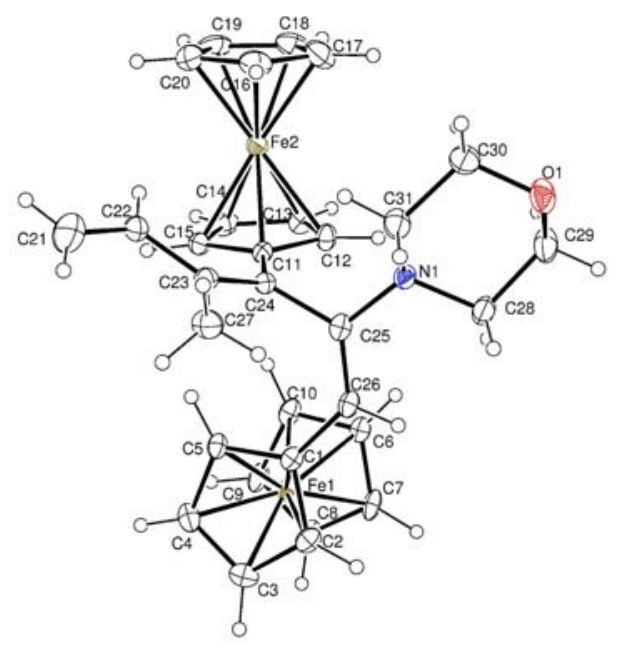

(b)

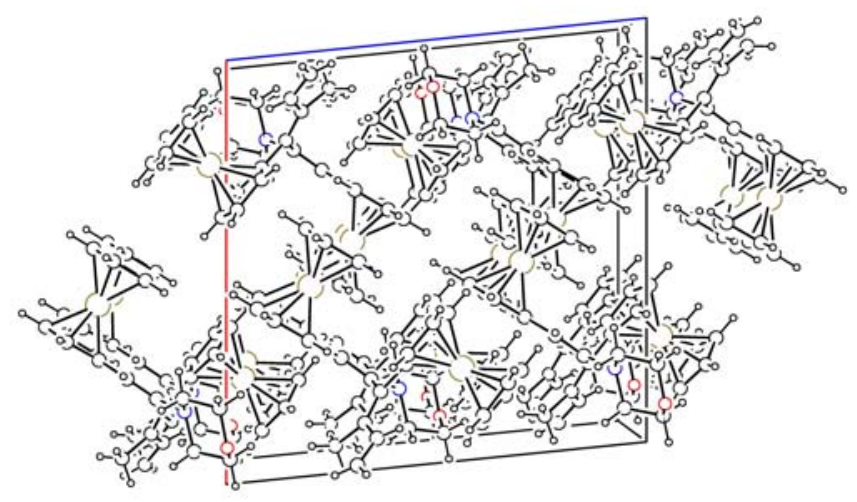

Figure 3. (a) X-ray crystal structure of 10b; (b) Crystal packing of $10 \mathbf{b}$.

(a)

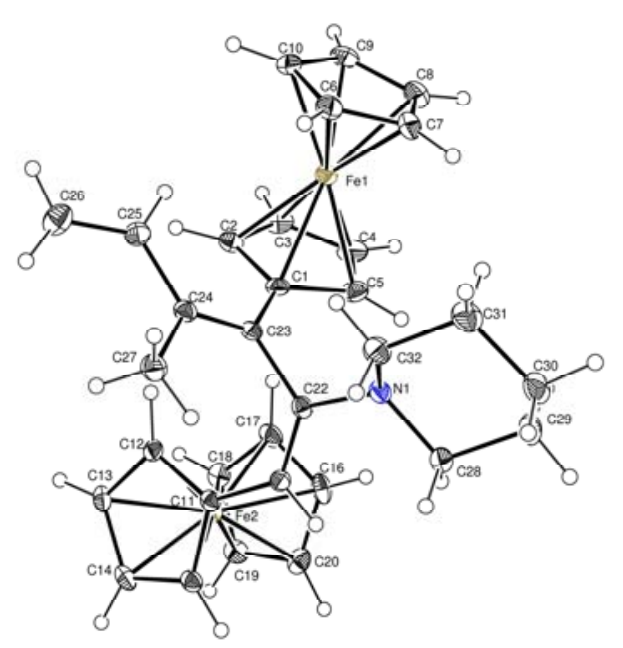

(b)

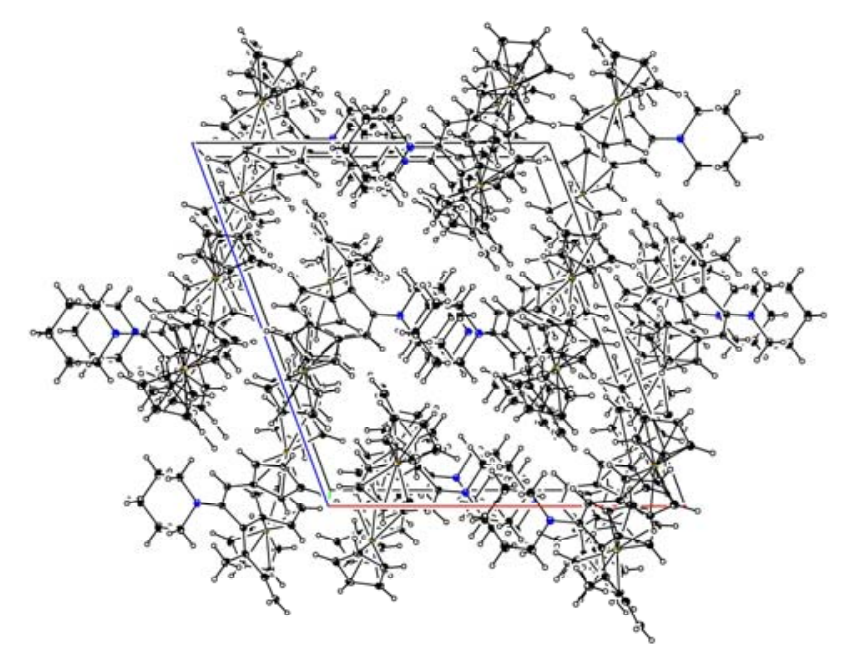

Compounds 11a and 11b were isolated as single geometrical isomers of $(Z, E)-1,2-$ diferrocenyl-3heteryl-4-methylhexa-1,3,5-trienes as inferred from the following data: the ${ }^{1} \mathrm{H}$ and ${ }^{13} \mathrm{C}$-NMR spectra of each of them contain signals for two ferrocenyl, one methyl, and one heterocyclic substituents, two olefinic $-\mathrm{CH}=$ and one terminal $\mathrm{CH}_{2}=$ group. Presumably, the $\mathrm{Z}$-arrangement of two ferrocenyl groups 
at the $\mathrm{C}(2)=\mathrm{C}(1)$ double bond was assigned based on comparison with cis-positions of two Fc-substituents in bicyclic products 8a,b. The E-configuration of the $\mathrm{C}(3)=\mathrm{C}(4)$ double bond was assigned based on comparison with $E$-configuration of the $\mathrm{C}(3)=\mathrm{C}(4)$ in trienes $\mathbf{1 0 a}, \mathbf{b}$.

The most feasible mechanism of the formation of compounds $\mathbf{6 ,} \mathbf{7}, \mathbf{8 a}, \mathbf{b}$, and 11a,b involves the initial nucleophilic attack of the 1-methylprop-2-enyl anion on the heteroaryl-substituted carbon atom of the three-carbon ring of the cations $\mathbf{1 a}$ and $\mathbf{1 b}$ to afford unstable 1,2-diferrocenyl-3-heteroaryl-3-(1methylprop-2-enyl)cyclopropenes 12a,b (Scheme 3).

Scheme 3. Plausible mechanism of the formation of $\mathbf{6 , 8 a , b}$ and 11a,b.

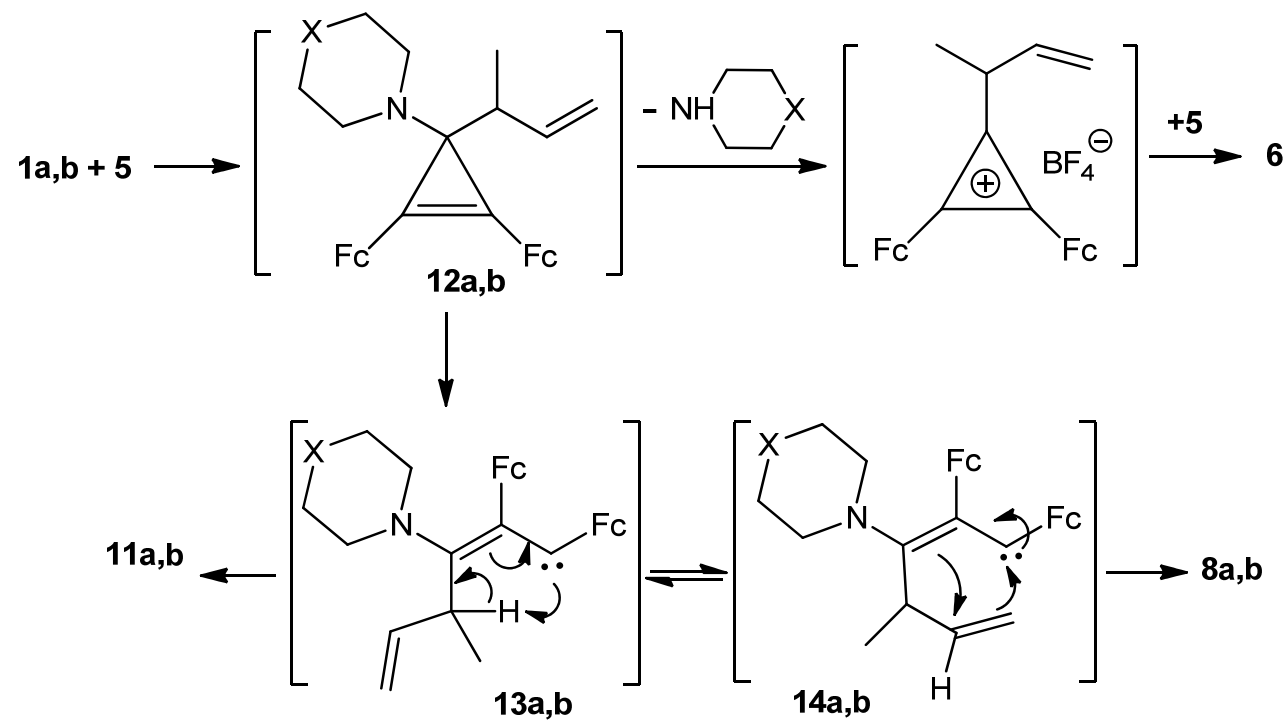

The transformation of cyclopropenes with retention of the 3-membered ring and elimination of the heterocyclic substituents results in cyclopropene 6 (Scheme 3). Opening of the cyclopropene ring gives rise to bicyclic 8a,b and linear triene products 11a,b via 1,2-diferrocenyl-3-heterylallylcarbenes 13a,b. In our opinion, cyclization of carbenes in their configuration 13a,b leads to bicyclic compounds 8a,b, while it is the intramolecular transformation of these carbenes in the configuration 14a,b results in (Z,E)-1,2-diferrocenyl-3-heteryl-4-methylhexa-1,3,5-trienes 11a,b (Scheme 3). On the other hand, intramolecular transformation of carbenes 14a,b with the loss of a heterocyclic substituent (Scheme 4) affords 3,4-diferrocenyltoluene 7 via transient 2,3-diferrocenyl-6-methylcyclohexa-2,5-dienylcarbene 15 (Scheme 4). Putative formation mechanisms of compounds 9a,b and 10a,b are depicted in Scheme 5.

Scheme 4. Plausible mechanism of the formation of 7.

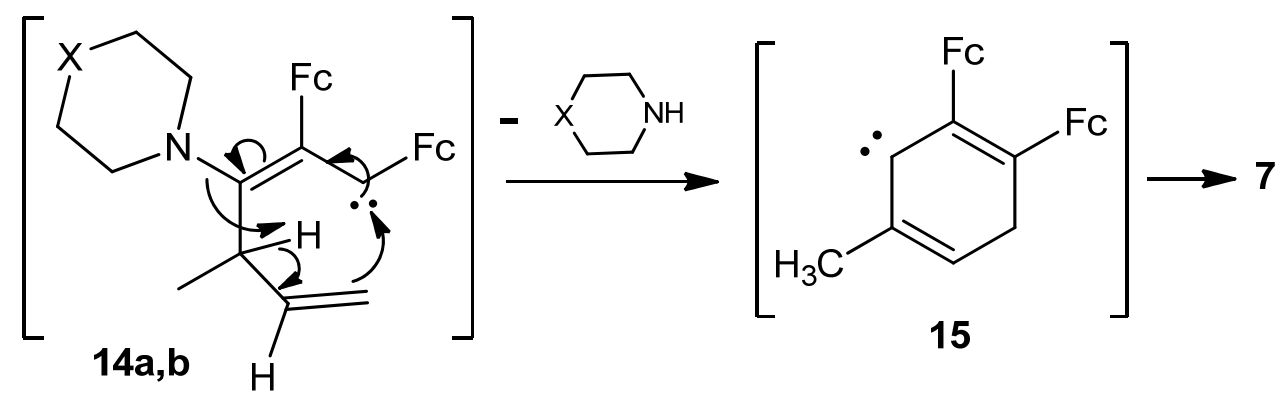


Scheme 5. Plausible mechanism of the formation of $\mathbf{9 a}, \mathbf{b}$ and $10 \mathbf{a}, \mathbf{b}$.
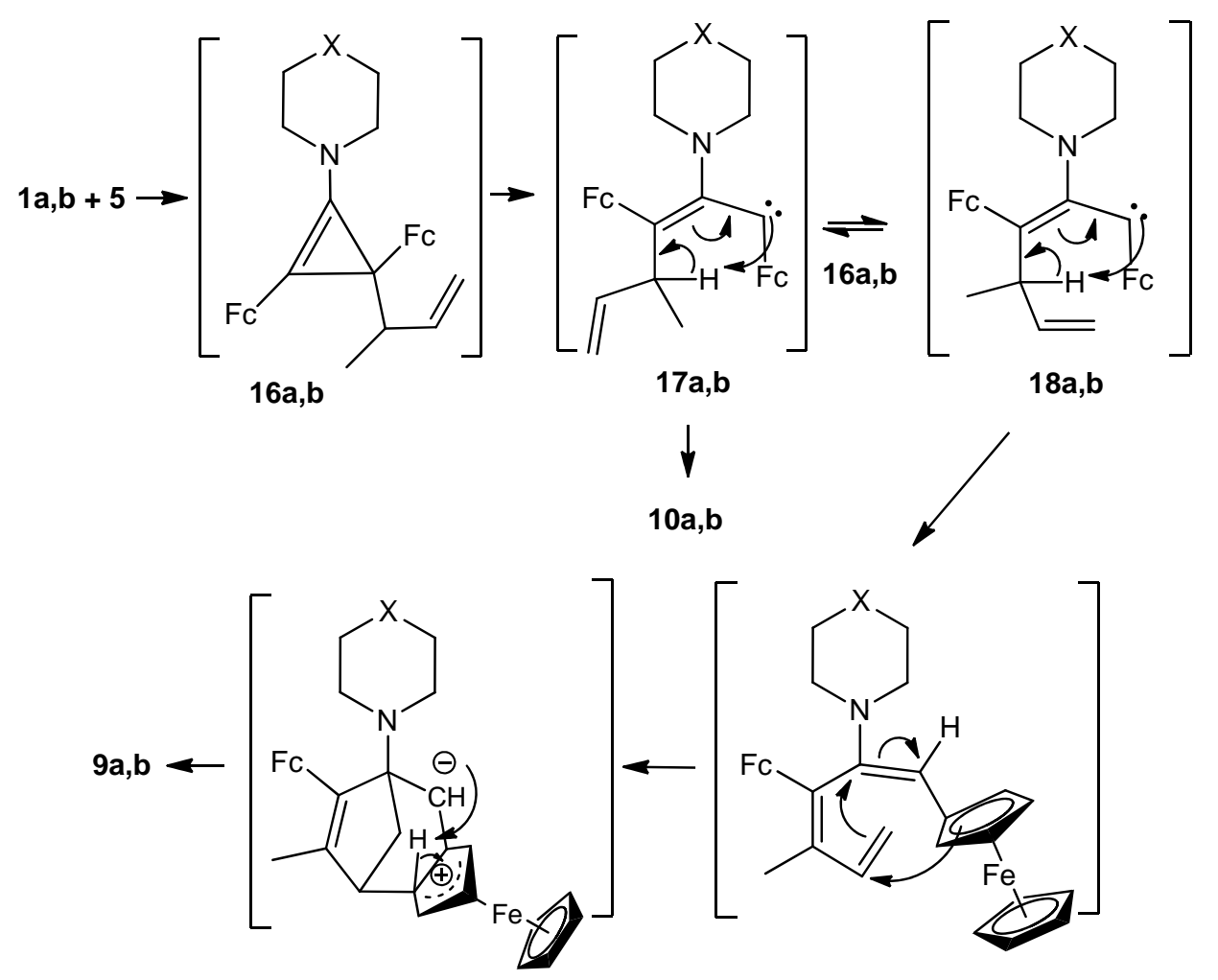

The primary nucleophilic attack on the $\mathrm{C}(2)$ atom of cyclopropenylium cations $\mathbf{1 a}$,b affords unstable tetrasubstituted cyclopropenes 16a,b. Small-ring opening in these transient species proceeds via 1,3-diferrocenyl-2-heterylallylcarbenes $\mathbf{1 7 a}, \mathbf{b}$ and $\mathbf{1 8 a}, \mathbf{b}$, their intramolecular transformations result in tricyclic 9a,b and linear 10a,b final products. Compounds 9a,b formed, like bicyclic products $\mathbf{8 a}, \mathbf{b}$, from carbenes with configuration 18a,b, while configuration $\mathbf{1 7 a}, \mathbf{b}$ of these carbenes gives rise to trienes 10a,b.

\subsection{Electrochemistry}

In the framework of this work, we studied electrochemical behavior of compounds 7, 8a, 10a and 10b by means of cyclic voltammetry and square wave voltammetry. Figure 4 shows a typical voltammogram of compound $\mathbf{7}$ obtained in a platinum electrode. Two oxidation signals $\left(\mathbf{I}_{\mathrm{a}}\right.$ and $\left.\mathbf{I I}_{\mathrm{a}}\right)$ with its complementary reduction signals $\left(\mathbf{I}_{\mathrm{c}}\right.$ and $\left.\mathbf{I I}_{\mathrm{c}}\right)$ were detected. The anodic and cathodic peak potential values were independent of scan rate, which indicates the reversibility of the two processes. The logarithmic values of peak current and scan rate were linearly dependent, with a slope near 0.5 ; this behaviour is characteristic for a diffusion-controlled process. This evidence indicates that processes I and II are attributed to two consecutive electron transfers of ferrocene moieties.

In order to obtain the formal electrode potential for both processes, square wave voltammetry experiments were carried out (Figure 5). The obtained values were $\mathrm{E}^{0^{\prime}}(\mathbf{I})=0.004 \mathrm{~V} / \mathrm{Fc}^{-\mathrm{Fc}^{+}}$and $\mathrm{E}^{0^{\prime}}(\mathbf{I I})=0.232 \mathrm{~V} / \mathrm{Fc}-\mathrm{Fc}^{+}$with its corresponding difference $\Delta \mathrm{E}^{0^{\prime}}$ (III-I) $=0.228 \mathrm{~V}$ and comproportionation constant $K_{\text {com }}$ of $7151.3[13,14]$. The electrochemical response of 8 a was similar than those described above for 7. 
Figure 4. Cyclic voltammograms obtained for 7 in the presence of $0.1 \mathrm{M} \mathrm{TBABF}_{4}$ in acetonitrile. Scan rate $0.5 \mathrm{~V} \mathrm{~s}^{-1}$. The scan potential was initiated from $\mathrm{E}_{\text {ocp }}$ in the positive direction. The working electrode used was a platinum disc.

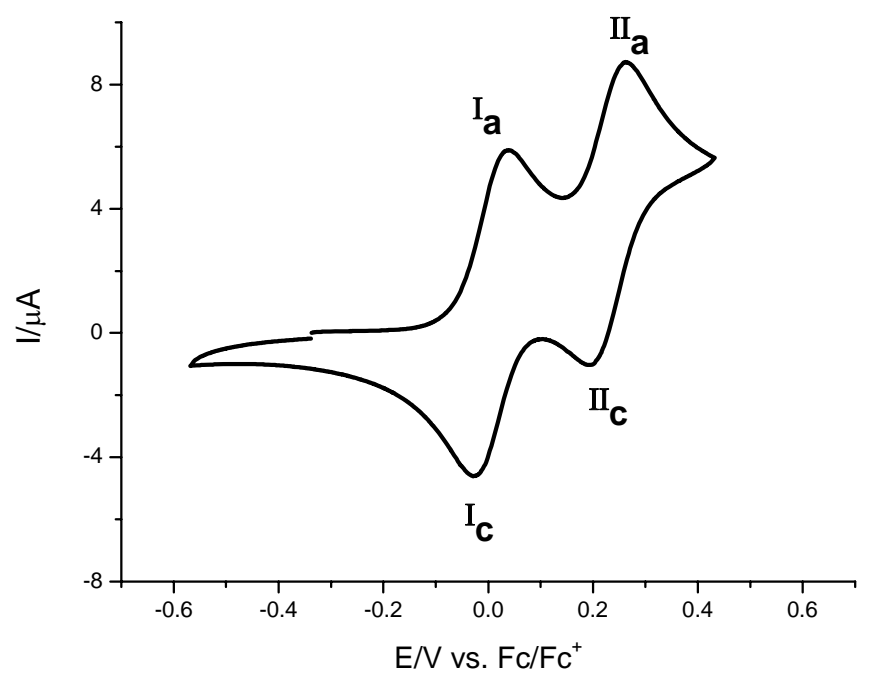

Figure 5. Square wave voltammetry obtained for 7 in the presence of $0.1 \mathrm{M} \mathrm{TBABF}_{4}$ in acetonitrile. Amplitude of $50 \mathrm{mV}$ with a frequency of $10 \mathrm{~Hz}$ and initiated from $\mathrm{E}_{\mathrm{ocp}}$ in the positive direction. The working electrode used was a platinum disc.

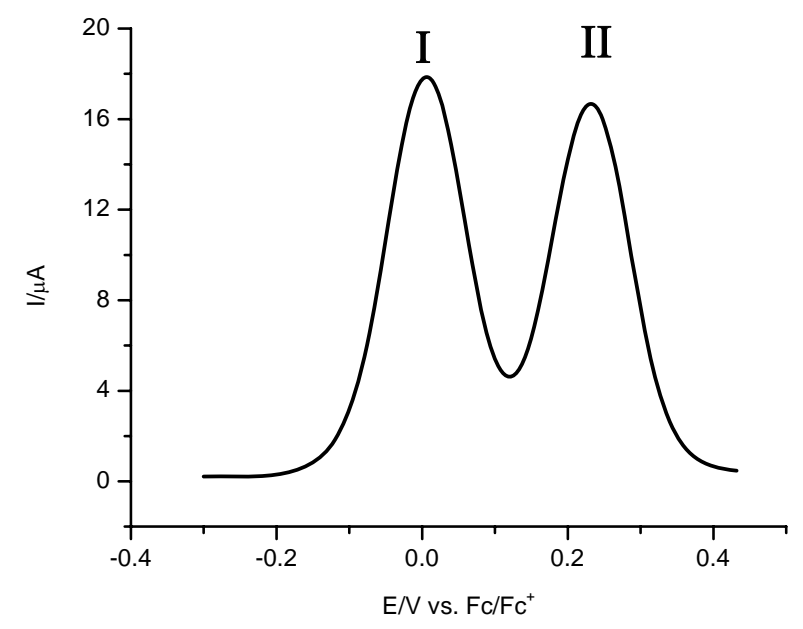

The estimated values of $\mathrm{E}^{0^{\prime}}(\mathbf{I})$ and $\mathrm{E}^{0^{\prime}}$ (II) were 0.058 and $=0.159 \mathrm{~V} / \mathrm{Fc}-\mathrm{Fc}^{+}$with $\Delta \mathrm{E}^{0^{\prime}}(\mathbf{I I}-\mathbf{I})=0.101 \mathrm{~V}$ and $K_{\text {com }}=51.4$. The highest value of $\Delta \mathrm{E}^{0^{\prime}}$ (II-I) for 7, compared with the obtained value for 8a, can be explained in terms of an increase in the electron density in ferrocene moieties due to the presence of an aromatic ring and the activating properties of the methyl substituent in 7 . This fact suggests that in the $K_{\text {com }}$ values electron withdrawing an electron donating effects must be consider. Also, the difference in the conjugation manner in compounds 7 and $\mathbf{8 a}$ could be the reason for the difference in $\Delta \mathrm{E}^{0^{\prime}}$ (II-I) values. Figure 6 presents cyclic voltammoamperometric response of compound 10a. When the potential scan was initiated in the positive direction, three oxidation signals ( $\mathbf{I}_{\mathrm{a}}, \mathbf{I I}_{\mathrm{a}}$, and $\left.\mathbf{I I}{ }^{\prime}{ }_{\mathrm{a}}\right)$ were observed, and when the potential scan was reversed, two reduction signals ( $\mathbf{I}_{\mathrm{c}}$ and $\mathbf{I I}{ }_{\mathrm{c}}$ ) were also observed. We propose that the electrochemical process $\mathbf{I}$ with its corresponding oxidation and reduction signals, $\mathbf{I}_{\mathrm{a}}$ and $\mathbf{I}_{\mathrm{c}}$, are attributed to electron transfer ferronece/ferricium ${ }^{+}$for both moieties. 
This is in agreement with the fact that a single electrochemical process is observed when there is no electronic communication between two redox centers, due to the long distance within a molecule, as occurs in compound 10a (Figure 6).

Figure 6. Cyclic voltammograms obtained for 10a in the presence of $0.1 \mathrm{M} \mathrm{TBABF}_{4}$ in acetonitrile. Scan rate $0.5 \mathrm{~V} \mathrm{~s}^{-1}$. The scan potential was initiated from $\mathrm{E}_{\text {ocp }}$ in the positive direction. The working electrode used was a platinum disc.

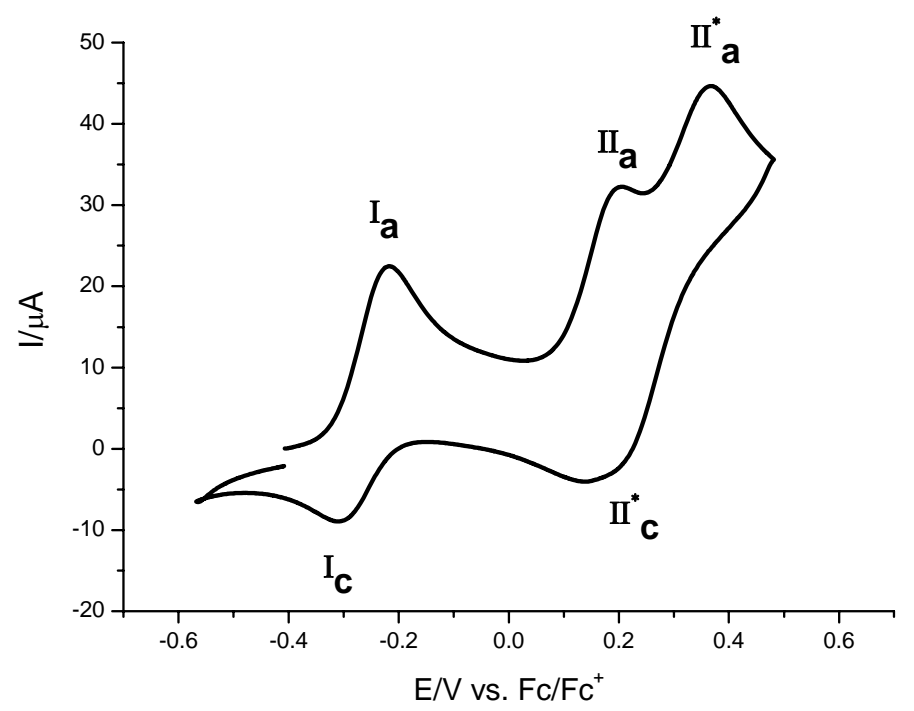

On the other hand, based on studies reported previously for molecules with conjugated double bonds, the processes II' a and II'" ${ }_{\text {a }}$ can be related to electrochemical generation of the monocation and dication species [15-21]. Controlled potential coulommetry experiments acquired at potential step corresponding to anodic peak potential values for processes I, and II, led us to calculate the value of two electrons transferred for each process. The formal electrode potential values were evaluated also using square wave voltammetry experiments (Figure 7).

Figure 7. Square wave voltammetry obtained for 10a in the presence of $0.1 \mathrm{M} \mathrm{TBABF}_{4}$ in acetonitrile. Amplitude of $50 \mathrm{mV}$ with a frequency of $10 \mathrm{~Hz}$ and initiated from $\mathrm{E}_{\text {ocp }}$ in the positive direction. The working electrode used was a platinum disc.

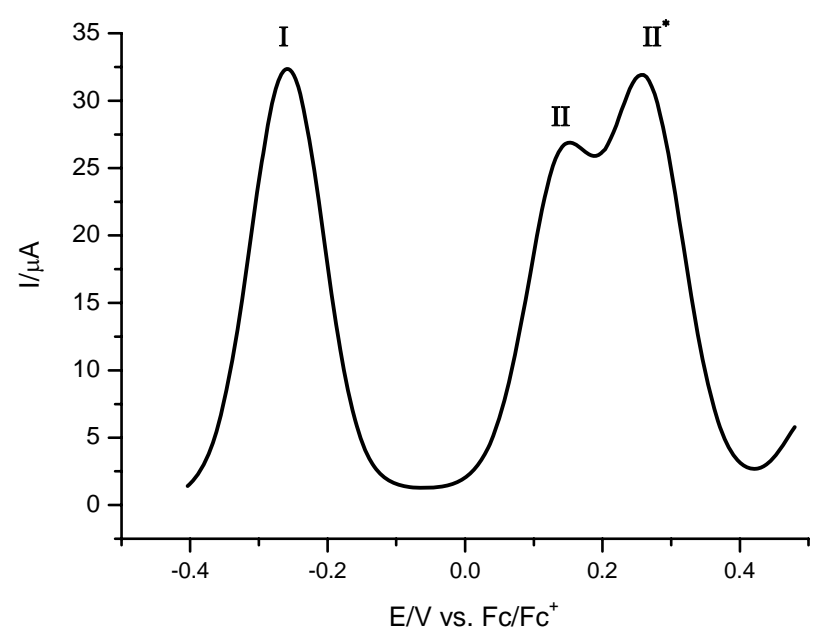


The values for $\mathrm{E}^{0^{\prime}}(\mathbf{I}), \mathrm{E}^{0^{\prime}}(\mathbf{I I})$, and $\mathrm{E}^{0^{\prime}}\left(\mathbf{I I}^{*}\right)$ were $-0.260,0.152$, and $0.256 \mathrm{~V} / \mathrm{Fc}-\mathrm{Fc}^{+}$, respectively. The electrochemical response of compound 10b is similar that obtained for 10a. However, different values of formal electrode potentials were observed. Table 2 shows a summary of electrochemical behaviour of compounds 7, 8a, 10a and 10b.

Table 2. Formal electrode potential $\mathrm{E}^{0}$ (I), $\mathrm{E}^{0}$ (II) and $\Delta \mathrm{E}^{0}$ (II-I), and constant $K_{\text {com }}$ for compounds 7, 8a, 10a, and 10b.

\begin{tabular}{ccccc}
\hline Compound & $\mathbf{E}^{\mathbf{0}}(\mathrm{I})^{\mathbf{a}}$ & $\mathbf{E}^{\mathbf{0}} \mathbf{( I I}^{\mathbf{a}}$ & $\mathbf{E}^{\mathbf{0}}\left(\mathrm{II}^{*}\right)^{\mathbf{b}}$ & $\left.\mathbf{E}^{\mathbf{0}} \mathbf{( I I}^{*}\right)^{\mathbf{c}}$ \\
\hline $\mathbf{7}$ & 0.004 & 0.232 & & \\
$\mathbf{8 a}$ & 0.058 & $0.101 \mathrm{~V}$ & & \\
$\mathbf{1 0 a}$ & $-0.260^{\mathrm{d}}$ & & 0.152 & 0.256 \\
$\mathbf{1 0 b}$ & $-0.328^{\mathrm{d}}$ & & 0.136 & 0.240 \\
\hline
\end{tabular}

\section{Experimental}

\subsection{General}

All the solvents were dried according to standard procedures [22] and were freshly distilled before use. Column chromatography and TLC were carried out on alumina (Brockmann activity III). The ${ }^{1} \mathrm{H}$ and ${ }^{13} \mathrm{C}-\mathrm{NMR}$ spectra of the compounds 6, 7 8a,b, 11a,b were recorded on a Unity Inova Varian spectrometer (300 and $75 \mathrm{MHz}$ ) for solutions in $\mathrm{CDCl}_{3}$, with $\mathrm{Me}_{4} \mathrm{Si}$ as the internal standard. The IR spectra were measured with an FTIR spectrophotometer (Spectrum RXI Perkin-Elmer instruments) using $\mathrm{KBr}$ pellets. UV spectra were recorded on a Specord UV-VIS spectrophotometer. The mass spectra were obtained on a Varian MAT CH-6 instrument (EI MS, 70 eV). A LECO CHNS-900 Elementar Analysensysteme was used for elemental analyses.

Electrochemical measurements were carried out in acetonitrile containing $0.1 \mathrm{M}$ tetra-n-butylammonium tetrafluoroborate $\left(\mathrm{TBABF}_{4}\right)$ with sample concentration c.a. $1 \mathrm{mM}$. An Epsilon-BAS potentiostat/galvanostat was used for all experiments. A typical three-electrode array was employed; using a platinum disk as working electrode and a platinum wire as counter-electrode. A silver wire immersed in acetonitrile solution with $0.1 \mathrm{M}$ tetra- $n$-butylammonium chloride (TBACl) was used as a pseudo reference electrode. Before each measurement all solutions were bubbled with nitrogen. Cyclic voltammetry experiments were acquired from the open circuit potential $\left(\mathrm{E}_{\mathrm{ocp}}\right)$ to positive direction, at different scan rates (from 0.1 to $0.5 \mathrm{~V} \mathrm{~s}^{-1}$ ). Square wave voltammetry experiments using amplitude of $50 \mathrm{mV}$ with a frequency of $10 \mathrm{~Hz}$ were also performed. All potentials were reported versus the $\mathrm{Fc} / \mathrm{Fc}^{+}$ couple, according to the IUPAC convention [23].

The following reagents were purchased from Aldrich: Tetrachlorocycloropropene, 98\%; ferrocene, 98\%; triethyloxonium tetrafluoroborate, $1.0 \mathrm{M}$ solution in dichloromethane; morpholine, 99.5\%; piperidine, 99\%; 1-methyl-2-propenylmagnesium chloride, $0.5 \mathrm{M}$ solution in tetrahydrofuran. Ethoxy(diferrocenyl)cyclopropenylium tetrafluoroborate was obtained by treating 2,3-diferrocenylcyclopropenone [2] in dichloromethane with triethyloxonium tetrafluoroborate. Diferrocenyl(morpholino)or (piperidino)cyclopropenylium tetrafluoroborates 1a,b were obtained from ethoxy(diferrocenyl)cyclopropenylium tetrafluoroborate and morpholine or piperidine in dichloromethane [1]. 
Reactions of diferrocenyl(morpholino)- or (piperidino)cyclopropenylium tetrafluoroborates 1a,b with 1-methyl-2-propenylmagnesium chloride (5). 1-Methyl-2-propenylmagnesium chloride (5, $20.0 \mathrm{~mL}$ of a $0.5 \mathrm{M}$ solution in tetrahydrofuran) was added to a suspension of salt $\mathbf{1 a}$ or $\mathbf{1 b}(5.0 \mathrm{mmol})$ in dry benzene $(100 \mathrm{~mL})$ and the mixture was stirred in an inert dry atmosphere $\left(\sim 70-80^{\circ} \mathrm{C}\right)$ until complete dissolution of the salts 1a,b occurred $(\sim 6-8 \mathrm{~h})$. The excess of the organometallic compound was quenched with water $(20 \mathrm{~mL})$, the organic layer was separated, concentrated, and the residue was chromatographed on alumina (Brockmann activity III, hexane-dichloromethane, 7:1) to give compounds 6, 7, 8a-11a and 8b-11b.

1,2-Diferrocenyl-3,3-di-(3-buten-2-yl)cyclopropene (6). Orange powder, yield: 0.18-0.26 g (7\%-10\%), m.p. $103-104{ }^{\circ} \mathrm{C}$ (hexane); ${ }^{1} \mathrm{H}-\mathrm{NMR}: 0.88$ (d, 3H, $\left.\mathrm{CH}_{3}, J=6.9 \mathrm{~Hz}\right), 1.11\left(\mathrm{~d}, 3 \mathrm{H}, \mathrm{CH}_{3}, J=6.9 \mathrm{~Hz}\right)$, $2.65(\mathrm{~m}, 2 \mathrm{H}, 2 \mathrm{CH}), 4.19\left(\mathrm{~s}, 5 \mathrm{H}, \mathrm{C}_{5} \mathrm{H}_{5}\right), 4.21\left(\mathrm{~s}, 5 \mathrm{H}, \mathrm{C}_{5} \mathrm{H}_{5}\right), 4.34\left(\mathrm{~m}, 3 \mathrm{H}, \mathrm{C}_{5} \mathrm{H}_{4}\right), 4.36\left(\mathrm{~m}, 3 \mathrm{H}, \mathrm{C}_{5} \mathrm{H}_{4}\right)$, $4.52\left(\mathrm{~m}, 2 \mathrm{H}, \mathrm{C}_{5} \mathrm{H}_{4}\right), 4.97-5.04\left(\mathrm{~m}, 4 \mathrm{H}, 2 \mathrm{CH}_{2}=\right), 5.84-5.98(\mathrm{~m}, 2 \mathrm{H}, 2 \mathrm{CH}=) ;{ }^{13} \mathrm{C}-\mathrm{NMR}: 18.63,18.81$ $\left(2 \mathrm{CH}_{3}\right), 42.66,43.19(2 \mathrm{CH}), 45.06(\mathrm{C}), 69.32,69.37\left(2 \mathrm{C}_{5} \mathrm{H}_{5}\right), 68.91,69.00,69.04,69.08,69.27,69.42$, 69.44, $69.46\left(2 \mathrm{C}_{5} \mathrm{H}_{4}\right), 76.04\left(2 \mathrm{C}_{\text {ipso }} \mathrm{Fc}\right), 112.58,112.88\left(2 \mathrm{CH}_{2}=\right), 144.87,144.95(2 \mathrm{CH}=), 144.56(2 \mathrm{C})$; MS: $m / 2516[\mathrm{M}]^{+}$. Anal. Calcd. for $\mathrm{C}_{31} \mathrm{H}_{32} \mathrm{Fe}_{2}$ : C, 72.11; H, 6.25; Fe, 21.64\%. Found: C, 72.23; H, $6.17 ; \mathrm{Fe}, 21.81$.

3,4-Diferrocenyltoluene (7). Orange powder, yield: $0.12-0.18$ g $(5 \%-8 \%)$, m.p. $124-125{ }^{\circ} \mathrm{C}$; ${ }^{1} \mathrm{H}-\mathrm{NMR}: 2.40\left(\mathrm{~s}, 3 \mathrm{H}, \mathrm{CH}_{3}\right), 4.00\left(\mathrm{~s}, 5 \mathrm{H}, \mathrm{C}_{5} \mathrm{H}_{5}\right), 4.02\left(\mathrm{~s}, 5 \mathrm{H}, \mathrm{C}_{5} \mathrm{H}_{5}\right), 4.04\left(\mathrm{~m}, 2 \mathrm{H}, \mathrm{C}_{5} \mathrm{H}_{4}\right), 4.06(\mathrm{~m}, 2 \mathrm{H}$, $\left.\mathrm{C}_{5} \mathrm{H}_{4}\right), 4.09\left(\mathrm{~m}, 4 \mathrm{H}, \mathrm{C}_{5} \mathrm{H}_{4}\right), 7.03\left(\mathrm{~d}, 1 \mathrm{H}, \mathrm{C}_{6} \mathrm{H}_{3} J=8.4 \mathrm{~Hz}\right), 7.55\left(\mathrm{~s}, 1 \mathrm{H}, \mathrm{C}_{6} \mathrm{H}_{3}\right), 7.62\left(\mathrm{~d}, 1 \mathrm{H}, \mathrm{C}_{6} \mathrm{H}_{3}\right.$ $J=8.4 \mathrm{~Hz}) ;{ }^{13} \mathrm{C}-\mathrm{NMR}: 21.17\left(\mathrm{CH}_{3}\right), 69.32,69.37\left(2 \mathrm{C}_{5} \mathrm{H}_{5}\right), 67.08,6715,70.56,70.65\left(2 \mathrm{C}_{5} \mathrm{H}_{4}\right), 87.81$, $87.83\left(2 \mathrm{C}_{i p s o} \mathrm{Fc}\right), 126.54,131.24,131.87\left(\mathrm{C}_{6} \mathrm{H}_{3}\right), 134.28,134.93,136.99\left(3 \mathrm{C}_{i p s o}\right)$; MS: $\mathrm{m} / \mathrm{z} 460[\mathrm{M}]^{+}$. Anal. Calcd. for $\mathrm{C}_{27} \mathrm{H}_{24} \mathrm{Fe}_{2}$ : C, 70.47; H, 5.26; Fe, 24.27. Found: C, 70.36; H, 5.40; Fe, 24.15 .

2,3-Diferrocenyl-6-methyl-1-morpholinobicyclo[3.1.0] hex-2-ene (8a). Orange oil, yield: 0.27 g (10\%); IR (KBr): 484, 755, 817, 876, 906, 969, 1002, 1031, 1044, 1106, 1119, 1172, 1220, 1263, 1302, 1360, 1449, 1614, 1714, 2250, 2734, 2851, 2955, $3093 \mathrm{~cm}^{-1}$; ${ }^{1} \mathrm{H}-\mathrm{NMR}: 0.94$ (m, 1H, CH), 1.04 (d, 3H, $\mathrm{CH}_{3}$, $J=6.9 \mathrm{~Hz}), 1.77(\mathrm{~m}, 1 \mathrm{H}, \mathrm{CH}), 2.35\left(\mathrm{dd}, 1 \mathrm{H}, \mathrm{CH}_{2}, J=4.8,16.5 \mathrm{~Hz}\right), 2.63\left(\mathrm{dd}, 1 \mathrm{H}, \mathrm{CH}_{2}, J=6.6,16.5 \mathrm{~Hz}\right)$, $2.78\left(\mathrm{~m}, 4 \mathrm{H}, 2 \mathrm{CH}_{2}\right), 3.48\left(\mathrm{~m}, 4 \mathrm{H}, 2 \mathrm{CH}_{2}\right), 3.91\left(\mathrm{~s}, 5 \mathrm{H}, \mathrm{C}_{5} \mathrm{H}_{5}\right), 4.00\left(\mathrm{~s}, 5 \mathrm{H}, \mathrm{C}_{5} \mathrm{H}_{5}\right), 3.84\left(\mathrm{~m}, 2 \mathrm{H}, \mathrm{C}_{5} \mathrm{H}_{4}\right)$, $3.89\left(\mathrm{~m}, 2 \mathrm{H}, \mathrm{C}_{5} \mathrm{H}_{4}\right), 3.94\left(\mathrm{~m}, 2 \mathrm{H}, \mathrm{C}_{5} \mathrm{H}_{4}\right), 4.04\left(\mathrm{~m}, 2 \mathrm{H}, \mathrm{C}_{5} \mathrm{H}_{4}\right) ;{ }^{13} \mathrm{C}-\mathrm{NMR}: 13.12,20.54(2 \mathrm{CH}), 20.63$ $\left(\mathrm{CH}_{3}\right), 34.23\left(\mathrm{CH}_{2}\right), 40.38,50.13\left(4 \mathrm{CH}_{2}\right), 65.09(\mathrm{C}), 68.43,68.75\left(2 \mathrm{C}_{5} \mathrm{H}_{5}\right), 67.21,67.42,67.61,67.89$, 68.52, 68.91, 69.54, $69.71\left(2 \mathrm{C}_{5} \mathrm{H}_{4}\right), 82.80,83.14\left(2 \mathrm{C}_{i p s o} \mathrm{Fc}\right), 133.45,135.12(2 \mathrm{C})$; MS: $\mathrm{m} / \mathrm{z} 547[\mathrm{M}]^{+}$. Anal. Calcd. for $\mathrm{C}_{31} \mathrm{H}_{33} \mathrm{Fe}_{2} \mathrm{NO}$ : C, 68.03; H, 6.08; Fe, 20.41; N, 2.56. Found: C, 67.96; H, 6.13; Fe, $20.55 ; \mathrm{N}, 2.60$.

7-Ferrocenyl-3,4-ferroceno-6-methyl-1-morpholinobicyclo[3.2.1]oct-6-ene (9a). Orange crystals, yield: 0.82 g (30\%), m.p. $167-168{ }^{\circ} \mathrm{C}$; IR (KBr): 497, 802, 809, 820, 998, 1025, 1106, 1153, 1304, 1390, 1442, 1465, 1630, 1715, 1768, 2184, 2793, 2918, 2952, 2976, 3075, $3107 \mathrm{~cm}^{-1}$; ${ }^{1} \mathrm{H}-\mathrm{NMR}: 1.75$ (dd, $\left.1 \mathrm{H}, \mathrm{CH}_{2}, J=5.7,13.8 \mathrm{~Hz}\right), 1.85\left(\mathrm{~s}, 3 \mathrm{H}, \mathrm{CH}_{3}\right), 1.98\left(\mathrm{dd}, 1 \mathrm{H}, \mathrm{CH}_{2}, J=8.4,13.8 \mathrm{~Hz}\right), 2.36(\mathrm{~d}, 1 \mathrm{H}$, $\left.\mathrm{CH}_{2}, J=12.6 \mathrm{~Hz}\right), 2.62\left(\mathrm{~d}, 1 \mathrm{H}, \mathrm{CH}_{2}, J=12.6 \mathrm{~Hz}\right), 2.70\left(\mathrm{~m}, 2 \mathrm{H}, \mathrm{CH}_{2}\right), 2.93(\mathrm{~m}, 1 \mathrm{H}, \mathrm{CH}), 3.66(\mathrm{~m}, 4 \mathrm{H}$, $\left.2 \mathrm{CH}_{2}\right), 3.88\left(\mathrm{~m}, 4 \mathrm{H}, 2 \mathrm{CH}_{2}\right), 3.93\left(\mathrm{~s}, 5 \mathrm{H}, \mathrm{C}_{5} \mathrm{H}_{5}\right), 4.04\left(\mathrm{~s}, 5 \mathrm{H}, \mathrm{C}_{5} \mathrm{H}_{5}\right), 3.41(\mathrm{~m}, 1 \mathrm{H}), 3.82(\mathrm{~m}, 1 \mathrm{H}), 4.06$ $(\mathrm{m}, 1 \mathrm{H}), 4.28(\mathrm{~m}, 2 \mathrm{H}), 4.35(\mathrm{~m}, 1 \mathrm{H}), 5.30(\mathrm{~m}, 1 \mathrm{H})\left(\mathrm{C}_{5} \mathrm{H}_{4}, \mathrm{C}_{5} \mathrm{H}_{3}\right) ;{ }^{13} \mathrm{C}-\mathrm{NMR}: 17.01\left(\mathrm{CH}_{3}\right), 35.16,36.66$ 
$\left(2 \mathrm{CH}_{2}\right), 46.31(\mathrm{CH}), 57.42,67.71\left(4 \mathrm{CH}_{2}\right), 68.95(\mathrm{C}), 68.68,69.36\left(2 \mathrm{C}_{5} \mathrm{H}_{5}\right), 67.14,67.29,67.87$, 69.49, 70.22, 70.87, $72.91\left(\mathrm{C}_{5} \mathrm{H}_{4}, \mathrm{C}_{5} \mathrm{H}_{3}\right), 76.83,80.06,93.47\left(3 \mathrm{C}_{i p s o} \mathrm{Fc}\right), 136.22,139.37(2 \mathrm{C}) ; \mathrm{MS}: \mathrm{m} / \mathrm{z}$ $547[\mathrm{M}]^{+}$. Anal. Calcd. for $\mathrm{C}_{31} \mathrm{H}_{33} \mathrm{Fe}_{2} \mathrm{NO}$ : C, 68.03; H, 6.08; Fe, 20.41; N, 2.56. Found: C, 68.14; H, 5.97; Fe, 20.32; N, 2.41.

E,E-1,3-Diferrocenyl-4-methyl-2-morpholinohexa-1,3,5-triene (10a). Orange crystals, yield: 0.62 g (22\%), m.p. $174-176^{\circ} \mathrm{C}$. $\lambda_{\max }\left(\mathrm{CHCl}_{3}, 2{ }^{\circ} \mathrm{C}\right) 211,282 \mathrm{~nm}$; IR (KBr): 490, 817, 906, 1000, 1026, 1044, 1106, 1119, 1166, 1220, 1276, 1374, 1444, 1581, 1615, 1819, 2049, 2185, 2730, 2816, 2853, 2947, 3079, $3091 \mathrm{~cm}^{-1}$; ${ }^{1} \mathrm{H}-\mathrm{NMR}: 1.77$ (s, 3H, $\left.\mathrm{CH}_{3}\right), 2.92\left(\mathrm{~m}, 4 \mathrm{H}, 2 \mathrm{CH}_{2}\right), 3.68\left(\mathrm{~m}, 4 \mathrm{H}, 2 \mathrm{CH}_{2}\right), 4.00\left(\mathrm{~s}, 5 \mathrm{H}, \mathrm{C}_{5} \mathrm{H}_{5}\right)$, $4.14\left(\mathrm{~s}, 5 \mathrm{H}, \mathrm{C}_{5} \mathrm{H}_{5}\right), 4.05\left(\mathrm{~m}, 2 \mathrm{H}, \mathrm{C}_{5} \mathrm{H}_{4}\right), 4.17\left(\mathrm{~m}, 1 \mathrm{H}, \mathrm{C}_{5} \mathrm{H}_{4}\right), 4.22\left(\mathrm{~m}, 1 \mathrm{H}, \mathrm{C}_{5} \mathrm{H}_{4}\right), 4.24\left(\mathrm{~m}, 1 \mathrm{H}, \mathrm{C}_{5} \mathrm{H}_{4}\right)$, $4.33\left(\mathrm{~m}, 1 \mathrm{H}, \mathrm{C}_{5} \mathrm{H}_{4}\right), 4.35\left(\mathrm{~m}, 1 \mathrm{H}, \mathrm{C}_{5} \mathrm{H}_{4}\right), 4.37\left(\mathrm{~m}, 1 \mathrm{H}, \mathrm{C}_{5} \mathrm{H}_{4}\right), 5.11(\mathrm{~s}, 1 \mathrm{H}, \mathrm{CH}=), 5.29\left(\mathrm{dd}, 1 \mathrm{H}, \mathrm{CH}_{2}=\right.$, $J=1.2,11.1 \mathrm{~Hz}), 5.35\left(\mathrm{dd}, 1 \mathrm{H}, \mathrm{CH}_{2}=, J=1.2,17.4 \mathrm{~Hz}\right), 7.89(\mathrm{dd}, 1 \mathrm{H}, \mathrm{CH}=, J=11.1,17.4 \mathrm{~Hz}){ }^{13} \mathrm{C}-\mathrm{NMR}$ : $16.60\left(\mathrm{CH}_{3}\right), 48.17,67.15\left(4 \mathrm{CH}_{2}\right), 69.01,69.39\left(2 \mathrm{C}_{5} \mathrm{H}_{5}\right), 67.18,67.30,67.62,67.66,67.95(2 \mathrm{C}), 70.95$, $71.52\left(2 \mathrm{C}_{5} \mathrm{H}_{4}\right), 84.96,85.23\left(2 \mathrm{C}_{i p s o} \mathrm{Fc}\right), 113.86\left(\mathrm{CH}_{2}=\right), 100.24,137.15(2 \mathrm{CH}=), 132.68,134.15$, 147.82 (3C); MS: $m / 2547[\mathrm{M}]^{+}$. Anal. Calcd. for $\mathrm{C}_{31} \mathrm{H}_{33} \mathrm{Fe}_{2} \mathrm{NO}$ : C, 68.03; H, 6.08; Fe, 20.41; N, 2.56. Found: C, 68.09; H, 6.14; Fe, 20.53; N, 2.38 .

Z,E-1,2-Diferrocenyl-4-methyl-3-morpholinohexa-1,3,5-trienes (11a). Orange oil, yield: $0.33 \mathrm{~g}$ (12\%). $\lambda_{\max }\left(\mathrm{CHCl}_{3}, 20{ }^{\circ} \mathrm{C}\right) 211,292 \mathrm{~nm}$; IR (KBr): 493, 815, 822, 865, 896, 1000, 1026, 1106, 1119, 1163 , 1226, 1249, 1301, 1386, 1446, 1625, 1651, 2298, 2852, 2956, $3091 \mathrm{~cm}^{-1}$; ${ }^{1} \mathrm{H}-\mathrm{NMR}: 1.95$ (s, 3H, $\left.\mathrm{CH}_{3}\right)$, $3.17\left(\mathrm{~m}, 4 \mathrm{H}, 2 \mathrm{CH}_{2}\right), 3.60-3.73\left(\mathrm{~m}, 4 \mathrm{H}, 2 \mathrm{CH}_{2}\right), 4.01\left(\mathrm{~s}, 5 \mathrm{H}, \mathrm{C}_{5} \mathrm{H}_{5}\right), 4.08\left(\mathrm{~s}, 5 \mathrm{H}, \mathrm{C}_{5} \mathrm{H}_{5}\right), 3.97(\mathrm{~m}, 2 \mathrm{H}$, $\left.\mathrm{C}_{5} \mathrm{H}_{4}\right), 4.20\left(\mathrm{~m}, 2 \mathrm{H}, \mathrm{C}_{5} \mathrm{H}_{4}\right), 4.28\left(\mathrm{~m}, 2 \mathrm{H}, \mathrm{C}_{5} \mathrm{H}_{4}\right), 4.37\left(\mathrm{~m}, 2 \mathrm{H}, \mathrm{C}_{5} \mathrm{H}_{4}\right), 5.15\left(\mathrm{dd}, 1 \mathrm{H}, \mathrm{CH}_{2}=, J=0.9,11.4 \mathrm{~Hz}\right)$, $5.36\left(\mathrm{dd}, 1 \mathrm{H}, \mathrm{CH}_{2}=, J=0.9,16.8 \mathrm{~Hz}\right), 6.25(\mathrm{~s}, 1 \mathrm{H}, \mathrm{CH}=), 7.03(\mathrm{dd}, 1 \mathrm{H}, \mathrm{CH}=, J=11.4,16.8 \mathrm{~Hz})$; ${ }^{13} \mathrm{C}-\mathrm{NMR}: 15.87\left(\mathrm{CH}_{3}\right), 45,84,65.13\left(4 \mathrm{CH}_{2}\right), 68.88,69.12\left(2 \mathrm{C}_{5} \mathrm{H}_{5}\right), 68.46,68.81,69.34,70.12\left(2 \mathrm{C}_{5} \mathrm{H}_{4}\right)$, 80.76, $82.60\left(2 \mathrm{C}_{i p s o} \mathrm{Fc}\right), 116.72\left(\mathrm{CH}_{2}=\right), 128.62,134.06(2 \mathrm{CH}=), 132.42,133.74,148.13$ (3C); MS: $m / 2547[\mathrm{M}]^{+}$. Anal. Calcd. for $\mathrm{C}_{31} \mathrm{H}_{33} \mathrm{Fe}_{2} \mathrm{NO}$ : C, 68.03; H, 6.08; Fe, 20.41; N, 2.56. Found: C, 67.87; H, 6.01; Fe, 20.31; N, 2.24.

2,3-Diferrocenyl-6-methyl-1-piperidinobicyclo[3.1.0] hex-2-ene (8b). Orange oil, yield: 0.22 g (8\%); IR (KBr): 487, 761, 815, 874, 906, 966, 1001, 1017, 1024, 1103, 1117, 1175, 1214, 1263, 1303, 1360, 1444, 1617, 1716, 2247, 2723, 2867, 2909, $3093 \mathrm{~cm}^{-1}$; ${ }^{1} \mathrm{H}-\mathrm{NMR}: 0.89$ (m, 1H, CH), 0.97 (d, 3H, $\mathrm{CH}_{3}$, $J=6.9 \mathrm{~Hz}), 1.49\left(\mathrm{~m}, 2 \mathrm{H}, \mathrm{CH}_{2}\right), 1.76(\mathrm{~m}, 1 \mathrm{H}, \mathrm{CH}), 2.27\left(\mathrm{dd}, 1 \mathrm{H}, \mathrm{CH}_{2}, J=4.5,16.2 \mathrm{~Hz}\right), 2.46(\mathrm{dd}, 1 \mathrm{H}$, $\left.\mathrm{CH}_{2}, J=6.6,16.2 \mathrm{~Hz}\right), 2.63\left(\mathrm{~m}, 4 \mathrm{H}, 2 \mathrm{CH}_{2}\right), 3.04\left(\mathrm{~m}, 4 \mathrm{H}, 2 \mathrm{CH}_{2}\right), 3.87\left(\mathrm{~s}, 5 \mathrm{H}, \mathrm{C}_{5} \mathrm{H}_{5}\right), 3.98(\mathrm{~s}, 5 \mathrm{H}$, $\left.\mathrm{C}_{5} \mathrm{H}_{5}\right), 3.82\left(\mathrm{~m}, 2 \mathrm{H}, \mathrm{C}_{5} \mathrm{H}_{4}\right), 3.92\left(\mathrm{~m}, 2 \mathrm{H}, \mathrm{C}_{5} \mathrm{H}_{4}\right), 4.00\left(\mathrm{~m}, 2 \mathrm{H}, \mathrm{C}_{5} \mathrm{H}_{4}\right), 4.02\left(\mathrm{~m}, 2 \mathrm{H}, \mathrm{C}_{5} \mathrm{H}_{4}\right)$; ${ }^{13} \mathrm{C}-\mathrm{NMR}$ : 12.92, $20.46(2 \mathrm{CH}), 21.34\left(\mathrm{CH}_{3}\right), 32.45\left(\mathrm{CH}_{2}\right), 47.56\left(5 \mathrm{CH}_{2}\right), 33.87,40.19\left(5 \mathrm{CH}_{2}\right), 64.17(\mathrm{C}), 68.36$, $68.59\left(2 \mathrm{C}_{5} \mathrm{H}_{5}\right), 67.19,67.40,67.54,67.82,68.73,68.99,69.32,69.34\left(2 \mathrm{C}_{5} \mathrm{H}_{4}\right), 82.54,82.87\left(2 \mathrm{C}_{i p s o} \mathrm{Fc}\right)$, 132.62, 133.91 (2C); MS: $m / 2545[\mathrm{M}]^{+}$. Anal. Calcd. for $\mathrm{C}_{32} \mathrm{H}_{35} \mathrm{Fe}_{2} \mathrm{~N}$ : C, 70.48; H, 6.47; Fe, 20.48; N, 2.57. Found: C, 70.32; H, 6.54; Fe, 20.31; N, 2.35 .

7-Ferrocenyl-3,4-ferroceno-6-methyl-1-piperidinobicyclo[3.2.1] oct-6-ene (9b). Orange crystals, yield: 0.84 g (31\%), m.p. $198-199{ }^{\circ} \mathrm{C}$; IR (KBr): 498, 801, 810, 819, 999, 1024, 1105, 1153, 1307, 1394, 1439, 1464, 1629, 1715, 1764, 2184, 2797, 2912, 2941, 2971, 3075, $3103 \mathrm{~cm}^{-1}$; ${ }^{1} \mathrm{H}-\mathrm{NMR}: 0.87$ (m, $\left.2 \mathrm{H}, \mathrm{CH}_{2}\right), 1.44\left(\mathrm{~m}, 4 \mathrm{H}, 2 \mathrm{CH}_{2}\right), 1.85\left(\mathrm{~s}, 3 \mathrm{H}, \mathrm{CH}_{3}\right), 2.11\left(\mathrm{~m}, 4 \mathrm{H}, 2 \mathrm{CH}_{2}\right), 2.21\left(\mathrm{dd}, 1 \mathrm{H}, \mathrm{CH}_{2}, J=5.1,9.6 \mathrm{~Hz}\right)$, 
$2.33\left(\mathrm{~d}, 1 \mathrm{H}, \mathrm{CH}_{2}, J=9.6 \mathrm{~Hz}\right), 2.69\left(\mathrm{~d}, 1 \mathrm{H}, \mathrm{CH}_{2}, J=15.6 \mathrm{~Hz}\right), 2.92(\mathrm{~d}, 1 \mathrm{H}, \mathrm{CH}, J=5.1 \mathrm{~Hz}), 3.27$ (d, $\left.1 \mathrm{H}, \mathrm{CH}_{2}, J=15.6 \mathrm{~Hz}\right), 3.74\left(\mathrm{~s}, 5 \mathrm{H}, \mathrm{C}_{5} \mathrm{H}_{5}\right), 4.08\left(\mathrm{~s}, 5 \mathrm{H}, \mathrm{C}_{5} \mathrm{H}_{5}\right), 3.94(\mathrm{~m}, 1 \mathrm{H}), 3.97(\mathrm{~m}, 2 \mathrm{H}), 4.07$ (m, $2 \mathrm{H}), 4.31(\mathrm{~m}, 1 \mathrm{H}), 4.97(\mathrm{~m}, 1 \mathrm{H}), 5.30\left(\mathrm{C}_{5} \mathrm{H}_{4}, \mathrm{C}_{5} \mathrm{H}_{3}\right) ;{ }^{13} \mathrm{C}-\mathrm{NMR}: 15.99\left(\mathrm{CH}_{3}\right), 25.65,29.96,36.54$ $\left(3 \mathrm{CH}_{2}\right), 45.00(\mathrm{CH}), 26.99,48.44\left(4 \mathrm{CH}_{2}\right), 68.82(\mathrm{C}), 68.68,69.36\left(2 \mathrm{C}_{5} \mathrm{H}_{5}\right), 63.14,64.61,66.58,67.12$, 67.37, 67.78, $75.07\left(\mathrm{C}_{5} \mathrm{H}_{4}, \mathrm{C}_{5} \mathrm{H}_{3}\right), 80.34,83.90,91.81\left(3 \mathrm{C}_{i p s o} \mathrm{Fc}\right), 131.42,141.58(2 \mathrm{C}) ; \mathrm{MS}: \mathrm{m} / \mathrm{z} 545$ $[\mathrm{M}]^{+}$. Anal. Calcd. for $\mathrm{C}_{32} \mathrm{H}_{35} \mathrm{Fe}_{2} \mathrm{~N}$ : C, 70.48; H, 6.47; Fe, 20.48; N, 2.57. Found: C, 70.57; H, 6.32; $\mathrm{Fe}, 20.53$; N, 2.65 .

E,E-1,3-Diferrocenyl-4-methyl-2-piperidinohexa-1,3,5-triene (10b). Orange crystals, yield: $0.57 \mathrm{~g}(21 \%)$, m.p. $206-207{ }^{\circ} \mathrm{C} ; \lambda_{\max }\left(\mathrm{CHCl}_{3}, 2{ }^{\circ} \mathrm{C}\right)$ 211, $293 \mathrm{~nm}$; IR (KBr): 492, 819, 903, 1004, 1024, 1046, 1106, 1121, 1163, 1225, 1277, 1375, 1444, 1580, 1621, 1820, 2037, 2191, 2728, 2815, 2839, 2952, 3081, $3093 \mathrm{~cm}^{-1}$; ${ }^{1} \mathrm{H}-\mathrm{NMR}: 1.53\left(\mathrm{~m}, 6 \mathrm{H}, 3 \mathrm{CH}_{2}\right), 1.74\left(\mathrm{~s}, 3 \mathrm{H}, \mathrm{CH}_{3}\right), 2.96\left(\mathrm{~m}, 4 \mathrm{H}, 2 \mathrm{CH}_{2}\right), 3.97\left(\mathrm{~s}, 5 \mathrm{H}, \mathrm{C}_{5} \mathrm{H}_{5}\right)$, $4.15\left(\mathrm{~s}, 5 \mathrm{H}, \mathrm{C}_{5} \mathrm{H}_{5}\right), 4.01\left(\mathrm{~m}, 2 \mathrm{H}, \mathrm{C}_{5} \mathrm{H}_{4}\right), 4.12\left(\mathrm{~m}, 1 \mathrm{H}, \mathrm{C}_{5} \mathrm{H}_{4}\right), 4.20\left(\mathrm{~m}, 1 \mathrm{H}, \mathrm{C}_{5} \mathrm{H}_{4}\right), 4.22\left(\mathrm{~m}, 1 \mathrm{H}, \mathrm{C}_{5} \mathrm{H}_{4}\right)$, $4.34\left(\mathrm{~m}, 1 \mathrm{H}, \mathrm{C}_{5} \mathrm{H}_{4}\right), 4.36\left(\mathrm{~m}, 1 \mathrm{H}, \mathrm{C}_{5} \mathrm{H}_{4}\right), 4.37\left(\mathrm{~m}, 1 \mathrm{H}, \mathrm{C}_{5} \mathrm{H}_{4}\right), 5.05(\mathrm{~s}, 1 \mathrm{H}, \mathrm{CH}=), 5.24\left(\mathrm{dd}, 1 \mathrm{H}, \mathrm{CH}_{2}=\right.$, $J=1.5,11.1 \mathrm{~Hz}), 5.31\left(\mathrm{dd}, 1 \mathrm{H}, \mathrm{CH}_{2}=, J=1.5,17.4 \mathrm{~Hz}\right), 7.84(\mathrm{dd}, 1 \mathrm{H}, \mathrm{CH}=, J=11.1,17.4 \mathrm{~Hz}) ;{ }^{13} \mathrm{C}-\mathrm{NMR}$ : $16.48\left(\mathrm{CH}_{3}\right), 24.76\left(\mathrm{CH}_{2}\right), 26.35,44.86\left(4 \mathrm{CH}_{2}\right), 68.98,69.39\left(2 \mathrm{C}_{5} \mathrm{H}_{5}\right), 67.03,67.43,67.53,67.69$, 67.90, 69.37, 70.88, $71.78\left(2 \mathrm{C}_{5} \mathrm{H}_{4}\right), 85.43,85.91\left(2 \mathrm{C}_{i p s o} \mathrm{Fc}\right), 113.35\left(\mathrm{CH}_{2}=\right), 99.29,137.44(2 \mathrm{CH}=)$, 133.50, 133.79, 148.87 (3C); MS: $m / 2545[\mathrm{M}]^{+}$. Anal. Calcd. for $\mathrm{C}_{32} \mathrm{H}_{35} \mathrm{Fe}_{2} \mathrm{~N}: \mathrm{C}, 70.48 ; \mathrm{H}, 6.47 ; \mathrm{Fe}$, 20.48; N, 2.57. Found: C, 70.37; H, 6.58; Fe, 20.61; N, 2.49.

Z,E-1,2-Diferrocenyl-4-methyl-3-piperidinohexa-1,3,5-trienes (11b). Orange oil, yield: $0.43 \mathrm{~g}$ (16\%). $\lambda_{\max }\left(\mathrm{CHCl}_{3}, 20{ }^{\circ} \mathrm{C}\right)$ 211, $294 \mathrm{~nm}$; IR (KBr): 489, 812, 818, 860, 896, 1006, 1021, 1103, 1121, 1163, 1224, 1251, 1302, 1385, 1443, 1625, 1648, 2294, 2855, 2962, $3093 \mathrm{~cm}^{-1}$; ${ }^{1} \mathrm{H}-\mathrm{NMR}: 1.02-1.21$ (m, 2H, $\left.\mathrm{CH}_{2}\right), 1.34-1.45\left(\mathrm{~m}, 4 \mathrm{H}, 2 \mathrm{CH}_{2}\right), 1.90\left(\mathrm{~s}, 3 \mathrm{H}, \mathrm{CH}_{3}\right), 2.35\left(\mathrm{~m}, 4 \mathrm{H}, 2 \mathrm{CH}_{2}\right), 4.00\left(\mathrm{~s}, 5 \mathrm{H}, \mathrm{C}_{5} \mathrm{H}_{5}\right), 4.09$ (s, $\left.5 \mathrm{H}, \mathrm{C}_{5} \mathrm{H}_{5}\right), 3.85\left(\mathrm{~m}, 2 \mathrm{H}, \mathrm{C}_{5} \mathrm{H}_{4}\right), 3.93\left(\mathrm{~m}, 2 \mathrm{H}, \mathrm{C}_{5} \mathrm{H}_{4}\right), 4.13\left(\mathrm{~m}, 2 \mathrm{H}, \mathrm{C}_{5} \mathrm{H}_{4}\right), 4.22\left(\mathrm{~m}, 2 \mathrm{H}, \mathrm{C}_{5} \mathrm{H}_{4}\right), 5.12(\mathrm{dd}$, $\left.1 \mathrm{H}, \mathrm{CH}_{2}=, J=1.2,11.1 \mathrm{~Hz}\right), 5.24\left(\mathrm{dd}, 1 \mathrm{H}, \mathrm{CH}_{2}=, J=1.2,17.4 \mathrm{~Hz}\right), 6.18(\mathrm{~s}, 1 \mathrm{H}, \mathrm{CH}=), 6.97(\mathrm{dd}, 1 \mathrm{H}$, $\mathrm{CH}=, J=11.1,17.4 \mathrm{~Hz}) ;{ }^{13} \mathrm{C}-\mathrm{NMR}: 15.63,\left(\mathrm{CH}_{3}\right), 20.67\left(\mathrm{CH}_{2}\right), 25.95,37.86\left(4 \mathrm{CH}_{2}\right), 68.47,69.02$ $\left(2 \mathrm{C}_{5} \mathrm{H}_{5}\right), 68.17,68.23,69.25,70.01\left(2 \mathrm{C}_{5} \mathrm{H}_{4}\right), 81.04,82.47\left(2 \mathrm{C}_{i p s o} \mathrm{Fc}\right), 116.74\left(\mathrm{CH}_{2}=\right), 126.63,130.13$ $(2 \mathrm{CH}=), 131.65,134.01,147.29$ (3C); MS: $m / 2545[\mathrm{M}]^{+}$. Anal. Calcd. for $\mathrm{C}_{32} \mathrm{H}_{35} \mathrm{Fe}_{2} \mathrm{~N}: \mathrm{C}, 70.48 ; \mathrm{H}$, 6.47; Fe, 20.48; N, 2.57. Found: C, 70.55; H, 6.34; Fe, 20.60; N, 2.61.

\subsection{Crystal structures of $\mathbf{9 b}, \mathbf{1 0 a}$ and $\mathbf{1 0 b}$}

Crystals of 9b, 10a and 10b were obtained from dichloromethane. The unit cell parameters and the X-ray diffraction intensities of 10a were recorded on a Siemens P4 diffractometer, of $\mathbf{9 b}$ and $\mathbf{1 0 b}$ on a Gemini (detector Atlas CCD, Cryojet $\mathrm{N}_{2}$ ) diffractometer. The structure of compounds $\mathbf{9 b}, \mathbf{1 0 a}$ and $\mathbf{1 0 b}$ were solved by the direct method (SHELXS [24]) and refined using full-matrix least-squares on $F^{2}$.

Crystal data for $\mathrm{C}_{32} \mathrm{H}_{35} \mathrm{Fe}_{2} \mathrm{~N}(9 \mathrm{~b}): \mathrm{M}=545.31 \mathrm{~g} \mathrm{~mol}^{-1}$, monoclinic P21/n, $a=10.5528(9), \mathrm{b}=10.3965(9)$, $\mathrm{c}=22.888(2) \AA, \alpha=90, \beta=93.605(10), \gamma=90^{\circ}, \mathrm{V}=2506.1(4) \AA^{3}, \mathrm{~T}=130(2) \mathrm{K}, \mathrm{Z}=4$, $\rho=1.445 \mathrm{Mg} / \mathrm{m}^{3}, \lambda(\mathrm{Mo}-\mathrm{K} \alpha)=0.71073 \AA, \mathrm{F}(000)=1144$, absorption coefficient $9.429 \mathrm{~mm}^{-1}$, crystal size $0.444 \times 0.2658 \times 0.1397 \mathrm{~mm}^{3}$, index ranges $-12 \leq \mathrm{h} \leq 12,-12 \leq \mathrm{k} \leq 8,-27 \leq 1 \leq 27$, scan range $3.87 \leq \theta \leq 68.09^{\circ}, 4574$ independent reflections, $\mathrm{R}_{\mathrm{int}}=0.0757,14354$ total reflections, 
318 refinable parameters, final $\mathrm{R}$ indices $[\mathrm{I}>2 \sigma(\mathrm{I})] \mathrm{R}_{1}=0.0487, \mathrm{wR}_{2}=0.1299, \mathrm{R}$ indices (all data) $\mathrm{R}_{1}=0.0588, \mathrm{wR}_{2}=0.1388$, goodness-of-fit on $\mathrm{F}^{2} 1.083$, largest difference peak and hole $0.482 /-0.915 \mathrm{e}^{-3}$.

Crystal data for $\mathrm{C}_{31} \mathrm{H}_{33} \mathrm{Fe}_{2} \mathrm{NO}(\mathbf{1 0 a}): \mathrm{M}=547.28 \mathrm{~g} \mathrm{~mol}^{-1}$, monoclinic P21/c, $a=15.602(1), \mathrm{b}=10.598(2)$, $\mathrm{c}=15.362(1) \AA, \alpha=90, \beta=95.844(5), \gamma=90^{\circ}, \mathrm{V}=2526.9(5) \AA^{3}, \mathrm{~T}=298(2) \mathrm{K}, \mathrm{Z}=4, \rho=1.439 \mathrm{Mg} / \mathrm{m}^{3}$, $\lambda(\mathrm{Mo}-\mathrm{K} \alpha)=0.71073 \AA, \mathrm{F}(000)=1144$, absorption coefficient $1.173 \mathrm{~mm}^{-1}$, crystal size $0.6003 \times$ $0.4151 \times 0.0545 \mathrm{~mm}^{3}$, index ranges $-15 \leq \mathrm{h} \leq 19,-13 \leq \mathrm{k} \leq 9,-19 \leq 1 \leq 18$, scan range $3.25 \leq \theta \leq 26.62^{\circ}$, 5270 independent reflections, $\mathrm{R}_{\text {int }}=0.0456,11939$ total reflections, 317 refinable parameters, final $\mathrm{R}$ indices $[\mathrm{I}>2 \sigma(\mathrm{I})] \mathrm{R}_{1}=0.0551, \mathrm{wR}_{2}=0.1644, \mathrm{R}$ indices (all data) $\mathrm{R}_{1}=0.0715, \mathrm{wR}_{2}=0.1781$, goodness-of-fit on $\mathrm{F}^{2} 1.090$, largest difference peak and hole $1.348 /-0.600 \mathrm{e} \AA^{-3}$.

Crystal data for $\mathrm{C}_{32} \mathrm{H}_{35} \mathrm{Fe}_{2} \mathrm{~N}$ (10b): $\mathrm{M}=545.31 \mathrm{~g} \mathrm{~mol}^{-1}$, monoclinic P21/c, $a=15.5360(5), \mathrm{b}=10.2960(2)$, $\mathrm{c}=16.8430(5) \AA, \alpha=90, \beta=110.613(3), \gamma=90^{\circ}, \mathrm{V}=2521.70(12) \AA^{3}, \mathrm{~T}=130(2) \mathrm{K}, \mathrm{Z}=4$, $\rho=1.436 \mathrm{Mg} / \mathrm{m}^{3}, \lambda($ Mo $-\mathrm{K} \alpha)=0.71073 \AA, \mathrm{F}(000)=1144$, absorption coefficient $1.172 \mathrm{~mm}^{-1}$, crystal size $0.5175 \times 0.1764 \times 0.1143 \mathrm{~mm}^{3}$, index ranges $-15 \leq \mathrm{h} \leq 19,-11 \leq \mathrm{k} \leq 12,-20 \leq 1 \leq 20$, scan range $3.43 \leq \theta \leq 26.06^{\circ}, 4978$ independent reflections, $\mathrm{R}_{\text {int }}=0.0442,18609$ total reflections, 317 refinable parameters, final $\mathrm{R}$ indices $[\mathrm{I}>2 \sigma(\mathrm{I})] \mathrm{R}_{1}=0.0382, \mathrm{wR}_{2}=0.0979, \mathrm{R}$ indices (all data) $\mathrm{R}_{1}=0.0502, \mathrm{wR}_{2}=0.1020$, goodness-of-fit on $\mathrm{F}^{2} 0.990$, largest difference peak and hole $0.830 /-0.498 \mathrm{e}^{-3}$.

CCDC-804034 (for 9b), CCDC-804035 (for 10a) and CCDC-804036 (for 10b) contain the supplementary crystallographic data for this paper. These data can be obtained free of charge at www.ccdc.cam.ac.uk/const/retrieving.html [or from the Cambridge Crystallographic Data Centre, 12, Union Road, Cambrige CB2 IEZ, UK (Fax: +44-1223-336033; E-Mail: deposit@ccdc.cam.ac.uk or www: http://www.ccdc.cam.ac.uk).

\section{Conclusions}

The reactions of 1-amino-2,3-diferrocenylcyclopropenylium cations $\mathbf{1 a , b}$ with strong $\mathrm{C}$-nucleophiles are nonregioselective (unlike the reactions with $\beta$-dicarbonyl compounds). The carbanions attack the $\mathrm{C}(1)$ and $\mathrm{C}(2)$ atoms of the cyclopropenylium cations with equal probability to afford two types of tetrasubstituted cyclopropenes, viz., 3-amino-1,2-diferrocenyl- and 1-amino-2,3diferrocenylcyclopropenes. Intramolecular transformations of the latter formed due to opening of the three-membered ring giving rise to two types of diferrocenylvinylcarbene species 13a,b, 14a,b, 15 and 17a,b, 18a,b differing in location of ferrocenyl, methyl, allyl and heteroaryl substituents in the carbon chain. Their intramolecular conversions to cyclic, bicyclic, tricyclic and linear final products certainly form the basis for further investigations in the fields of theoretical and synthetic organic chemistry, the search for new methods for an access to practically valuable materials.

The electrochemical behaviour of compounds 7, 8a, 10a and 10b was investigated by means of cyclic voltammetry and square wave voltammetry. For $\mathbf{7}$ and $\mathbf{8 a}$ two electrochemical processes (I-II), attributed to the oxidation of the ferrocene moieties were found. On the other hand for compounds 10a and 10b a single electron transfer for both ferrocene groups and the electrochemical generation of the monocation and dication species were detected. 


\section{Acknowledgments}

This work was supported by the CONACyT (Mexico, grant Number 100970). The authors are grateful to E. A. Vázquez López for his technical assistance.

\section{Conflict of Interest}

The authors declare no conflict of interest.

\section{References and Notes}

1. Klimova, E.I.; Klimova, B.T.; Hernández Ortega, S.; Méndez Iturbide, D.; García Marquez, A.; Martínez García, M. Diferrocenylcyclopropenyl cations. Synthesis, structures, and some chemical properties. J. Organomet. Chem. 2005, 690, 3332-3335.

2. Klimova, E.I.; Klimova, T.; Betanzos Lara, S.; Dominguez Chavez, J.; Hernández Ortega, S.; Toscano, A.; Martínez García, M. Synthesis of stable 1-ethoxy-2,3-diferrocenylcyclopropenylium tetrafluoroborate and its reactions with lithium reagent. J. Organomet. Chem. 2006, 691, 1-8.

3. Klimova, B.T.; Martínez García, M.; Ortiz-Frade, L.; Hernández Ortega, S.; Toscano, R.A.; Klimova, E.I. Synthesis, structures and some chemical and electrochemical properties of E-1,2-diferrocenyl-3-methylthioprop-2-enone and its ketals. J. Organomet. Chem. 2006, 691, 2872-2882.

4. Klimova Berestneva, T.; Klimova, E.I.; Mèndez Stivalet, J.M.; Hernandez Ortega, S.; Martìnez Garcia, M. Diferrocenyl(methylthio)cyclopropenylium iodide in the synthesis of 2,3-diferrocenyl-1-methylthio-1,3-dienes and -1,3,5-trienes. Eur. J. Org. Chem. 2005, 4406-4413.

5. Klimova, E.I.; Klimova Berestneva, T.; Hernandez-Ortega, S.; Ortiz-Frade, L.A.; Backinowsky, L.V.; Martínez García, M. Synthesis of 1,2-diferrocenyl-3-(diacylmethylidene)cyclopropenes and 1,1-diacyl-2,3-diferrocenyl-4-methylsulfanylbuta-1,3-dienes, their structures and electrochemical properties. J. Organomet. Chem. 2008, 693, 1215-1224.

6. Klimova, E.I.; Mendez Stivalet, J.M.; Klimova Berestneva, T.; Flores Alamo, M.; Backinowsky, L.V.; Ortiz Frade, L.; Martìnez García, M. Reactions of diferrocenylmorpholinoand methylsulfanyl-cyclopropenylium salts with $\beta$-dicarbonyl compounds and diethyl malonate. Syn. Commun. 2010, 40, 839-854.

7. Klimova, E.I.; Klimova, T.; Flores Alamo, M.; Backinowsky, L.V.; Martìnez García, M. Intramolecular transformations of 3-cyanoamino- and 3-cyanoimino-1,2-diferrocenylcyclopropenes. Molecules 2009, 14, 3161-3175.

8. Schvekhgeimer, M.-G.A. Heterylferrocenes. Russ. Chem. Rev. 1996, 65, 80-112.

9. Klimova, E.I.; Klimova, T.; Ruiz Ramirez, L.; Cinquantini, A.; Corsini, M.; Zanello, P.; Hernandez Ortega, S.; Martinez Garcia, M. 2,3-Diferrocenylcyclopropenone: Synthesis, structure and some chemical and electrochemical properties. Eur. J. Org. Chem. 2003, 4265-4275.

10. Klimova, E.I.; Ruiz Ramirez, L.; Martinez García, M.; Espinosa, R.G.; Meleshonkova, N.N. Synthesis of biologically active compounds based on 2-ferocenylmethylene-3-quinuclidone. Russ. Chem. Bull. 1996, 45, 2602-2609. 
11. Klimova, E.I.; Sazonova, V.A.; Pushin, A.N. Reaction of 1,2-diferrocenylcyclopropanes with trityl tetrafluoroborate. Zh. Obshch. Khim. 1987, 57, 2336-2342.

12. Nesmeyanov, A.N.; Klimova, E.I.; Struchkov, Yu.T.; Postnov, V.N.; Andrianov, V.G.; Postnov, V.N.; Sazonova, V.A. Cyclopropanes with a ferrocenyl group. J. Organomet. Chem. 1979, 178, 343-348.

13. Bard, A.J.; Faulkner, L.R. Electrochemical Methods: Fundamentals and Applications, 2nd ed.; John Wiley and Sons: New York, NY, USA, 2001; Chapter 5.

14. Zanello, P. Inorganic Electrochemistry, Theory, Practice and Application; The Royal Society of Chemistry: Cambridge, UK, 2003.

15. Ferguson, G.; Glidewell, C.; Opromolla, G.; Zakaria, C.M.; Zanello, P. The redox behavior of some bis-ferrocenyl compounds: Cristal and molecular structures of diferrocenylmethane and diferrocenylmethanol. J. Organomet. Chem. 1996, 517, 183-186.

16. Khaled, M.; Hadjipetrou, A.; Kispert, L. Electrochemical and electron paramagnetic resonance studies of carotenoid cation radicals and dications: effect of deuteration. J. Phys. Chem. 1990, 94, 5164-5169.

17. Khaled, M.; Hadjipetrou, A.; Kispert, L.D; Allendoerfer, R.D. Simultaneous electrochemical and electron paramagnetic resonance studies of carotenoid cation radicals and dications. J. Phys. Chem. 1991, 95, 2438-2442.

18. Jeevarajan, A.S.; Khaled, M.; Kispert, L.D. Simultaneous electrochemical and electron paramagnetic resonance studies of carotenoids: Effect of electron donating and accepting substituents. J. Phys. Chem. 1994, 98, 7777-7781.

19. Gao, G.; Jeevarajan, A.S.; Kispert, L.D. Cyclyc voltammetry and spectroelectrochemical studies of cation radical and dication adsorption behaviour for 7,7'-diphenyl-7,7'-diapocarotene. J. Electroanal. Chem. 1996, 411, 51-56.

20. Jeevarajan, A.S.; Kispert, L.D. Electrochemical oxidation of carotenoids containing donor-acceptor substituents. J. Electroanal. Chem. 1996, 411, 57-66.

21. Blanchard, P.; Brisset, H.; Riou, A.; Hierle, R.; Roncali, J. Bridget 1,6-dithienylhexa-1,3,5-trienes as highly photoluminescent and stable thiophene-based $\pi$-conjugated systems. J. Org. Chem. 1998, 63, 8310-8319.

22. Robin, M.B.; Day, P. Mixed valence chemistry. A survey and classification. Adv. Inorg. Chem. Radiochem. 1967, 10, 247-422.

23. Gritzner, G.; Küta, J. Recommendations on reporting electrode potentials in nonaqueous solvets. Pure Appl. Chem. 1984, 54, 461-466.

24. Sheldrick, G.M. SHELXL-97, Program for the Refinement of Crystal Structures; University of Göttingen: Göttingen, Germany, 1994.

Sample Availability: Samples of the compounds $\mathbf{8 a}, \mathbf{9 b}, \mathbf{1 0 a}, \mathbf{b}$ are available from the authors.

(C) 2011 by the authors; licensee MDPI, Basel, Switzerland. This article is an open access article distributed under the terms and conditions of the Creative Commons Attribution license (http://creativecommons.org/licenses/by/3.0/). 